\title{
The Spectacle of Representation: Calendar Girls, the Gaze and the Atelier
}

\section{Martha E. Huang}

\section{(2) OpenEdition}

\section{Journals}

\section{Electronic version}

URL: http://journals.openedition.org/transtexts/87

DOI: $10.4000 /$ transtexts.87

ISSN: 2105-2549

\section{Publisher}

Gregory B. Lee

\section{Printed version}

Date of publication: 1 January 2007

Number of pages: 84-131

ISSN: 1771-2084

\section{Electronic reference}




\title{
The Spectacle of Representation: Calendar Girls, the Gaze and the Atelier
}

\author{
Martha E. HuANG
}

Dans un premier temps, cet article analyse la réception faite en Chine à l'art populaire $\mathrm{du}$ «calendrier » de ses origines au début du vingtième siècle jusqu'à nos jours, et en particulier aux jeunes femmes qui étaient les modèles chinois de ce mode de représentation d'inspiration occidentale. Dans un deuxième temps, sont examinées certaines oeuvres littéraires romanesques de la fin des Qing et du début de la République, en particulier de la période du 4 Mai, portant sur la production d'images féminimes et le regard qu'on leur portait

\begin{abstract}
A Poster
Look at the girl. She is waiting for a friend to go traveling. She is straight and slim, shoulders back, posed under a weeping willow budding in spring green. She is wearing a white cheongsam, embroidered or printed with red chrysanthemums and green leaves, of a silk so soft that the shape of her breasts is visible. She has a soft grey overcoat or shawl draped over her left arm, and her right hand is raised, perhaps in greeting and also to brush a strand of willow away. She is smiling, and looks slightly to the left, her gaze is welcoming. She is saying to someone, "Look, over here, here I am."
\end{abstract}

The signature in the lower left hand corner of the poster reads Zhiying. Hang 
Zhiying 杭穉英 (1900-1947) trained at the Commercial Press in Shanghai, but left in the early 1920's to open his own atelier, the Zhiying Studios. ${ }^{1}$ Specializing in promotional art and packaging, the Studios, with their stable of talented artists, soon held a large share of the commercial art market. ${ }^{2}$ Their range of posters ran from the most expensive, with calendar (sometimes including both Western and lunar dates), decorative frames, optional smaller landscape insets above or below the main image, poetic inscriptions, reproductions of the product advertised, and sometimes an overlay of gilt; to the cheapest-- a "hanger", in which the design of a pretty girl was printed on a plain background with a thin metal strip attached at the top for hanging. Such prints advertised nothing except perhaps a certain aesthetic, but were popular as a cheap form of interior decoration. "Waiting to go traveling" was a hanger, which meant that the image had not been selected for use by advertisers.

The address under the signature is Sima Lu 四马路, otherwise known as Fuzhou Road 福州路, in the old Chinese section of Shanghai. Famous for its pleasure houses and bookshops, the road was also the city's printing centre. Spatial geography ran parallel to cultural geography--like Fuzhou Road, the advertising art produced there was a space of leisure, desire, temptation and consumption, and therefore perched uneasily on the borders of social acceptance. Highly successful as a marketing tool, accepted by the urban populace as decorative items in their homes, these works posed a problem for, and a challenge to, Chinese intellectuals.

If one listens to the testimony of survivors from this period, these calendars girls were unimportant. When asked his opinion of these posters in the spring of 1997, Shi Zhecun 施哲存, a modernist writer best known for introducing the works of Freud in China, replied, "These types of things were simply for uneducated people. If we intellectuals wanted to hang something on the wall, we would choose a reproduction of a real artistic work, something more classical, like David's portrait of Napoleon, for example." ${ }^{3}$ Similarly, in a conversation with Feng Chuyin 冯倠音, widow of Zhang Leping 张乐平, the cartoonist who created San Mao 三毛 in 1935, still one of China's most popular comic book characters, Ms. Feng insisted that she

${ }^{1} \mathrm{Ng}$ Chun Bong, et. al., compilers, Chinese Woman and Modernity: Calendar Posters of the 1910s-1930s, Hong Kong, Joint Publishing Co., Ltd., 1996, p.162.

2Ellen Johnston. Laing Selling Happiness: Calendar Posters and Visual Culture in Early Twentieth-

Century Shanghai, Honolulu, University of Hawaii Press, 2004, p.205.

3Interview with Shi Zhecun. Shanghai, spring 1997. 
and her husband had nothing to do either with such art or their artists. ${ }^{4}$

It would be easy to explain this type of denial by the succession of purges undertaken by the PRC government under Mao Zedong, when any trace of capitalist culture was condemned, punished and erased. In fact, it might be argued that much of the cultural experience of Shanghai in the first half of the 20th century was repressed and silenced, as the city's past became, even more than Taiwan or any country in the West, a symbol of all that the Chinese Community Party had fought against. ${ }^{5}$

It was only in the late 1980s, with the reform of economic policy, that the positive reclamation of Old Shanghai began, including the rediscovery of Shanghai writers, the recovery of films produced in the early Shanghai studios, the celebration of the city's early architecture, graphic design and fashion, and of course, the unearthing of its advertising images.

By the mid-1990s, calendar art was already being reproduced--or rather, counterfeited-in China as a small coterie of collectors from Japan, Taiwan, Hong Kong and the West had begun to display and write about these images. ${ }^{6}$ The impending handover of Hong Kong to China in 1997 and the consequent conflation of nostalgias-one already present for a pre-revolutionary Paris of the East; the other anticipated for a post-colonial hybridized urban metropolis about to revert to Chinese rule--created a bigger demand for the posters, and opened a new market for Shanghai advertising recapitulated in the form of books, recordings, postcards,

\footnotetext{
${ }^{4}$ Interview with Feng Chuyin. Shanghai, spring 1997. According to Zhang's biographers, however, Zhang did spend some time as a young trainee at an advertising agency in Shanghai that produced nothing but calendar art. The young artist had no interest in painting only beautiful women, preferring to draw ordinary people in their daily lives. He was fired by his opium-smoking boss when he produced a cartoon of two opium addicts inhaling on an opium bed. See: Xiao Ding 萧丁, “Zhang Leping xiao zhuan" 张乐平小传传 (“A brief biography of Zhang Leping") in Wang Yiqiu 王亦秋, ed., Zhang Leping lianhuan manhua quanji 张乐平连环漫画全集 (The complete comic strips of Zhang Leping). Beijing: Lianhuan manhua chubanshe, 1994, (unpaginated, page 2 of the short biography).

${ }^{5}$ For an interesting view of how Shanghai's wicked past was presented in early post-Liberation China, see Shen Ximeng 沈西蒙, et al, Nihongdeng xia de shaobing 霓虹灯下的哨兵 (Sentry under the neon lights), a comic book originally produced in 1965, and reprinted in 2004.

'Zhang Yanfeng 张燕风, “Lao yuefenpai guanggaohua” 老月份牌廣告画, Hansheng Zazhi 汉声杂志， No. 61. two volumes, Taipei, 1994., Cheuk Pak Tong 卓伯棠, a television and film producer in HK, produced a series of articles on calendar art which appeared in the Taipei bi-monthly Lianhe Wenxue 联 合文学 in 1993-4: “Zhongguo yuefenpai de yange” 中国月份牌画的沿革, LHWX, no. 106, August 1993. “Guan Huinong yu Zhonghuo zaoqi shangpin haibao” 关蕙农与中国早期商品海报, LHWX, no. 115, May 1994.
} 
coasters, t-shirts, and other product packaging.

When Shi Zhecun and Feng Chuyin were interviewed in early 1997, Shi, who had taught modern Chinese literature for years at East China Normal University but had never been able to mention his own or his friends' work in class, was just beginning to see his early short stories studied in China. Foreign researchers had "re-discovered" his work over a decade before. ${ }^{7}$ The family of Zhang, the comic artist who had been pilloried during the Cultural Revolution, was in the midst of pursuing a groundbreaking lawsuit to protect the copyright of San Mao as a brand image. Still, these intellectuals refused to reserve any space in their cultural memories for calendar art other than in the back alleys and back rooms of the lower classes.

\section{An Exchange}

In January 1919, the latest issue of the popular student magazine New Youth (Xin qingnian 新青年) carried a lead article by Gao Yihang 高一函 on “The Basic Mistake of the Peace Conference" (Heping huiyide genben cuowu 和平会义的根本 错误). It was clear by then that negotiations in Versailles at the end of the First World War were not going well for China. Discontent over the signings in April would culminate in the student movements later that May. But tucked away on page 84 was a letter to the editor entitled, "A revolution in the arts" (Meishu geming 美术革命), from a student named Lu Cheng 吕溦.

Lu begins by drawing a parallel between the literary reform movement promoted by New Youth and the one inaugurated in 1909 by Marinetti in Italy. "Now when people talk about Futurism", says Lu, "there are even those who forget [that it was] a literary movement." Why? Because Futurism very quickly turned to the task of revolutionizing visual arts-something which China also desperately needs to address. What becomes clear in Lu's diatribe, however, is that his main concern is with the growing commercialization and consequent corruption of painting-specifically painting as it is practiced in Shanghai:

“When we speak of painters, very few do not push commercial houses to use paintings of ladies (shinü hua 士女画) as brand images. The blame rests with

7See Gregory Lee, Dai Wangshu: The Life and Poetry of a Chinese Modernist; Hong Kong: Chinese University Press, 1988. Lee interviewed Shi extensively in the early1980s. See also Lee's chapter on Chinese modernism: "Chinese Modernism, Western Colonialism" in Lee, Gregory, Troubadours, Trumpeters, Troubled Makers. London: Hurst \& Company, 1996. Isabelle Lee, working in French, produced the first translations of Shi Zhecun's stories in the 1980s. 
the artists, and there are few who do not mistake this type of unreasonable painting for ability." ${ }^{\prime 8}$

“驯至今日，言绘画者几莫不推商家用为号招之仕女画为上。其自居为 画家者，亦几无不以作此类不合理之绘画为能。”

He further notes:

"For Shanghai artists, only this type of painting can succeed, but the faces do not distinguish between masculine and feminine (bubie yinyang 不别阴阳) and the limbs are not in proportion--this is commonplace. There is no knowledge at all of anatomy. As to the subjects, all have been selected according to sex appeal, which is regrettable." 9

“上海画工，惟此种画间能成巧；然其面目不别阴阳，四肢不称全体， 则比比是。盖美术解剖学, 纯非所知也。至于画题, 全从引起肉感设想 ，成堪叹息。”

More generally, the problem is that painting is now the province of mass culture and common people cannot distinguish between what is good or bad. Lu calls for the magazine to take up the cause of revolutionizing the arts; only New Youth has the power and influence to do it. "Be the second Italian poetry magazine!" he pleads, again evoking Marinetti and the Futurists, "the benefits will not be limited to just one people or one time."

Editor Chen Duxiu's 陈独秀 response on behalf of the paper is interesting. He admits that he has long wanted to take up the reform of both medicine and the arts. Following Lu's lead in joining literature to fine arts, he states that like the Chinese literary revolution which has realism at its crux, new Chinese art must take verisimilitude as its standard. It is only by painting what is real that Chinese artists can move away from repetitive forms and genres and be free to use both their creative talent and their descriptive technique. ${ }^{10}$

Chen, writing from Beijing, takes as his examples painters who are in vogue in the capital, where the problem is neither the confused absorption of Western style, nor the corrupting power of commerce, but the strict adherence to palace paintings. For him, a proponent of vernacular baihua 白话 style who has no time for a lament over the loss of high style, and who has led the fight against old literary forms like

${ }^{8}$ Lu Cheng, "Meishugeming”, in Xin Qingnian, Vol. VI, No. 1, p.85.

${ }^{9}$ Lu Cheng, p. 85.

${ }^{10}$ Chen Duxiu, response to "Meishugeming", in Xin Qingnian, Vol. VI, No. 1, p. 86. 
the eight-legged essay, it is the emphasis placed on copying old artistic forms that is holding back new Chinese art.

Chen Duxiu only addresses the issue of calendar art at the very end of his note. He then classifies it as one of the three "strange creatures born of a single mother" -Shanghai, "that immature and absurd place"-- which also include mixed-sex new style theatre and the second- and third-hand translations of western works by the Tongcheng 桐城 group into classical Chinese. ${ }^{11}$ The metaphors of miscegenation and stillbirth are clear. Chen does not bother with Shanghai or its defective hybrid offspring because he does not expect them to last long.

The New Youth exchange highlights some important issues. First, there is Lu Cheng's positioning of calendar art in relation to art. Although he protests that its practitioners are not real artists, he also admits that no one is sure anymore what real art is. He tries to draw a distinction between high and low art, by distinguishing art produced by literati from that produced by artisans, but then admits that in the end common people have no way of determining what is beautiful. His reasons for throwing calendar art out of the inner circle are mixed. Western art is too fleshy and lascivious, and appeals to man's baser instincts. When its power is put to commercial use, the effect is even greater. What is worse in his mind is the growth of spurious and misleading arts education, in the form of courses, magazines, and fake lecturers.

"In the magazines they publish, in terms of teaching anything about art, they speak in vague and amorphous terms, sometimes even plagiarizing directly; they also produce all sorts of things, and speak of Western art without distinguishing the different schools in a superficial and arbitrary way, who knows what harm this may do!"12

“其刊行之杂志, 学艺拦所载, 皆拉杂浮廓之谈; 且竟有直行抄袭以成者; 又 杂沮载畣问, 竟谓西洋画无派别可言; 浅学武断, 为害何限。”

What is needed, he suggests, is a clear précis of Chinese art from the Tang dynasty to the present, with all of its schools and trends, and the same again for Western art, so that place, time, and aesthetic trends will not be confused. For the present, there are too many images, they are too popular, and, Lu seems to imply, the

\footnotetext{
${ }^{11}$ Chen Duxiu, p. 86 :至于上海新流行的仕女画他那幼稚和荒谬的地方, 和男女拆白党演的新剧, 和不懂西 文的桐城派古文宗译的新小说, 好像是一母所生的三个怪物。要把这三个怪物当作新文艺不禁为新文艺放 声一哭。此覆还求赐教。

${ }^{12}$ Lu Cheng, p.85.
} 
Chinese public has no tools with which to negotiate them, or defend against them.

The importation of Western art has upset traditional epistemological patterns. Foreign knowledge in China has been traditionally the preserve of the intellectual elite, but in the case of Western art it is the commercial artists, pushed by technology and economic demand, who have taken up the techniques first, albeit in an unsystematic and unschooled way. The implication is that because these "artisans" have no commitment to the orthodox order, they have no reason to resist a new one. Moreover, because they are not well educated, they are unable to contain--or have no interest in containing--the dangerous power of this new imported imagery. The result is that Lu could be disturbed by the sexuality of the shinü hua, even while he complained they were badly drawn.

Lu's arguments, earnest and sometimes confused, crystallized much of the intellectual anxiety about calendar art and about popular culture in general. To men who sought to learn from the West, the posters represented the dangers of a careless mating. Calendar artists learned from the West, but in a way not mediated by intellectuals. They portrayed modern women, but with no other social agenda except to sell goods and make money. Their works found a ready market, produced in numbers that no intellectual magazine or book could hope to reach. Their images had direct communicative power, but catered to lower instincts instead of higher ones, creating desire instead of assuaging it.

Not much is known about Lu Cheng. In early 1919 he was young and had had some training in art history. His prose was clumsy, the stodginess of the wenyan he would have practiced in middle school barely containing the impassioned prudishness of a young university student. In contrast, Chen's reply is almost Olympian, set down in the crystalline new baihua that he himself has helped to formulate. Yet one senses that the 40 year-old professor's prose, with its elegant parallel logic, is in some ways even more constraining. There is no room in his writing for the mess of popular desire and its expression. Thus his is yet another intellectual strategy towards this new kind of art--to simply ignore it.

\section{Representations}

Calendar art did not fade away. In the following two to three decades, the illustrative techniques of calendar art would go from strength to strength, while the images themselves shifted and changed, reflecting an increasingly diverse and demanding market. As Ellen Johnston Laing notes, "nothing could stop the flow of 
annual calendars...[which] were both advertisements for commodities and themselves commodities to be advertised."13 Laing, in her definitive work on calendar art, Selling Happiness: Calendar Posters and Visual Culture in Early-TwentiethCentury Shanghai, provides an invaluable narrative of the development of these images through an examination of their material context-focusing on the mechanics of production as well as the demands of an evolving marketplace. ${ }^{14} \mathrm{In}$ addition, Laing conducts an impressive exploration into the personalities and lives of the painters who produced the work, a much needed antidote to the easy abstraction of these images as direct romantic reflections of urban Shanghai culture.

It is easy to be seduced by the content of the posters. The images are obvious material for studies in feminist history or material culture. They are records of contemporary desire, the women meticulously constructed figures, embodying the wish-fulfillment of a consumer culture in which beautifully groomed women dressed in the latest fashions are surrounded by luxurious furnishings and objects imported from around the world.

Calendar art implies art produced quickly and cheaply, in response to changing tastes and the quickening of modern, clock-kept time. Mass reproduction implies the quick and easy stamping of images, but in the context of Chinese painting, it is art produced by cutting images into stone and applying coats of color in laborious stages (lithography). It lies somewhere in the middle of two traditions, the slow layering of paint in European oils, and the quick breathing strokes of the Chinese watercolor. In addition, the prints were designed to appear "fresh" to the eye for at least a year, since the entire calendar year is printed on the same page. Production process and function thus imbue the posters with a kind of permanence that belies the fashionability (and therefore the ephemerality) of their content.

As a topic of art history, calendar art represents a nexus between the modern commercial imagery of the West, and the long tradition of looking at paintings of beautiful or exemplary women in Chinese art. Although Laing has connected some of the lines between the artists who produced commercial art with the modern fine arts movements of their time, there are still lines of inquiry to be opened up across the obstructive boundaries between high and low art. ${ }^{15}$ The training of calendar

\footnotetext{
${ }^{13}$ Ellen Johnston Laing, Selling Happiness: Calendar Posters and Visual Culture in Early-TwentiethCentury Shanghai. Honolulu: University of Hawaii Press, 2004. p. 61.

${ }^{14}$ Laing, p. 305

${ }^{15}$ Laing, p. 166.
} 
artists often took place in the same classrooms and studios as the training of future Western influenced producers of Chinese modern art, and one can argue that the problematic of depicting the nude, for example, remains the same, whether the image is destined for an art gallery or a printing press.

Who are these women? And perhaps an equally valid question---Who are they not? Catherine Vance Yeh's work on the late Qing Shanghai courtesan cultural sphere allows us to extend the historical context of calendar art back into the mid-1800s. In Shanghai Love: Courtesans, Intellectuals and Entertainment Culture, 1850-1910, Yeh shows us the production of images of women who make the transition from women performers and companions highly valued in the closed world of the high literati to businesswomen who find stages for their arts outside the "flower houses", in the streets and stages and parks of semi-colonial Shanghai. ${ }^{16}$ These women became personalities in newspapers, characters in serial novels, images in photographs that advertised their places of business; while their patrons and admirers became--instead of government officials--journalists, freelance novelists and critics. Their images ranged from the line drawings in early illustrated magazines such as Dianshizhai huabao 點石齋畫報 (established Shanghai 1884) to photographs in advertising cards and courtesan newspapers. These were the first mass produced images of women, women who had highly individualized media identities, and until the Republican period, women whose company was explicitly for sale.

The transition from courtesan to calendar girl was sporadic and arguably incomplete. Both characters were commercial ones, but in order for images of beautiful girls to be effective as advertising art, they needed a cleaner back-story. To be the screen upon which the viewer's desires were projected, the figures needed to be desirable but anonymous (or generic, in the case of film stars), and they needed not to be prostitutes. Even within the courtesan world there were standards. The standing of one of the earliest artists Zheng Mantuo 郑曼陀(1888-1961) collapsed, after the model for one of his most successful calendars was revealed to have been a beautiful streetwalker. When it became public higher class prostitutes boycotted his studio and work. ${ }^{17}$ On the other hand, we have the apocryphal story of his first calendar girl, in which Zhang visits the theatre, and in the audience notices sitting nearby a "sweet and fair" beauty who smiles at him engagingly. The next day he sees an advertisement by the Commercial Press calling for calendar art, and

${ }^{16}$ Catherine Vance Yeh, Shanghai Love: Courtesans, Intellectuals, and Entertainment Culture, 1850-1910. Seattle: University of Washington Press, 2006. p. 430.

${ }^{17}$ Laing, p. 126. 
immediately draws her from memory, taking first place. ${ }^{18}$ What is interesting here is that while the background of the girl might only be slightly ambiguous (what other type of girl would be sitting in a public theatre in 1914 Shanghai), she does not go so far as to pose. The artist recreates her after one sighting, he has no relationship with her other than a smile. Through the 1910's and into the 1920's, the image of the calendar girl changes from a pretty girl in the crowd who just may be a courtesan, to a young educated modern girl who enjoys the freedom her wealthy family has granted her. By the 1930s she is back to being a working girl, but as a film star who acts as a prostitute but must guard from becoming one in real life.

There is one other thing she is not. She is not white. She is Chinese. It is an obvious but important distinction. As we will see, men and women students could look dispassionately at representations of European women, dressed or undressed. Representations of Chinese women, however, were something else. It is easy to explain the first by the estrangements of "race", and the second by the discomforts of sexual familiarity and identity. But we must assume that the tension goes deeper. There exists, after all, a long tradition of looking at images of beautiful women in China. In The Double Screen: Medium and Representation in Chinese Painting, Wu Hung locates the moment when "female images began to change from political and moral symbols to objects of visual appreciates and sexual desire". He finds it in a handscroll dating from the Northern Wei, The Nymph of the Luo River, "the first Chinese painting devoted to the subject of romantic love." 19 By the early twentieth century, then, there is already an established ritual of looking at "beautiful woman" paintings (meiren hua 美人画), at “feminine space" (what Wu defines as a "spacial entity" in which a woman, presented to the male gaze, is part of a landscape "in which flowers and plants reflect her radiance and luxury, and mirrors and screens reveal her loneliness and sorrow") that has lasted for more than a millennium and a half. ${ }^{20}$

The male gaze transmits power and desire over a female object. But what is newly disturbing about looking at images of Chinese women at the turn of the century is that the mode of representation is Western. The constructing "eye" of the image, is a foreign one. Even if the painter is Chinese, the newly trained eye with which he looks at the girl is not. The logic is relentless. If any eye colonizes its object, in

\footnotetext{
${ }^{18}$ Hansheng Magazine, No. 61, Taibei:Hansheng zazhishe, 1994. pp. 87-88.

${ }^{19} \mathrm{Wu}$ Hung, The Double Screen: Medium and Representation in Chinese Painting. London: Reaktion Books, 1996. p. 95.

${ }^{20}$ Wu Hung, p. 211.
} 
modern Western portraiture and calendar art in China, the Western eye doubly colonizes the Chinese model. In the transitional context of early twentieth century China, the intensity of the gaze and its effects were amplified in meaning. The artist, whether working in oil paint or lithography, was playing with fire.

The tenets of effective advertising demanded that commercial images be Chinese so that Chinese audiences would relate to them. The problem was that the images themselves were compromised from their very conception within the context of capitalist modernity and semi-colonialism.

How were these images looked at then? How are we to look at them now? What did it mean to look at a pretty girl standing frozen in time and in space? What does it mean still?

\section{Literary Representations}

Parallel to the technical innovations in the production of these images, was the development of critical responses to them. Periodically, there would be tirades, much like Lu Cheng's, against the general phenomenon of commercial art. Intellectuals denounced the loss of traditional landscapes increasingly overgrown with building signs, billboards, and posters, just as they ruefully watched the meditative contemplation of art and nature give way to the frenzied consumption that was the response to advertising. ${ }^{21}$

What is more interesting is that over time, the penetration of commercial art and design into the public consciousness elicited a response from other forms of representation-in fiction and essays, and in theater and film. The reaction might consist of something as simple as a calendar poster hanging on the wall of a character's room, or a narrator who compares a woman he meets to a girl in a cigarette advertisement. Through these literary texts, it is possible to see calendar art and its depictions of women as spectacular events, as writers found the imaginary room in which to explore the problematic of posing, looking, (re)producing, considering, consuming and processing these new images.

\footnotetext{
${ }^{21}$ See Laing, who cites Lu Xun's public denunciation at an art lecture in 1920. “Not only are calendar painters unskilled but the subjects of their paintings are disgusting and depraved." p. 37. See also Barme, Geremie R. An Artistic Exile: A Life of Feng Zikai (1898-1975). Berkeley: University of California Press, 2002, p. 208: "Zikai railed against these images, which were being passed off as a vital new form of mass commercial art; to his eye they were creations 'remarkable from their poverty of both form and content"'.
} 
The literary depiction of making images of women runs parallel to the production of the images themselves. There is the Yuan dynasty play "Autumn in the Han Palace" (Hangongqiu 汉宫秋, by Ma Zhiyuan 马致远 (1250-1321), taken from “Miscellaneous Anecdotes of the Western Capital" (Xijing zazhi 西京杂志, Han dynasty) in which the Han emperor Yuandi directs his adviser to scour the country for beautiful women, and hire artists to paint portraits so that he can make his choice more conveniently. The advisor is corrupt and asks for money to make the portraits more flattering. The family of the beautiful Wang Zhaojun is poor and cannot afford his fees, and so Wang's portrait is defaced and she is ignored by the emperor. Later the emperor inadvertently discovers Wang's beauty and condemns the adviser to death. Wang is sent to the Xiongnu tribes, married to the king there, and later commits suicide. Ultimately, says Richard Vinograd, the story is about the "corruption and destruction of representation." 22

The act of representation has enormous power, implying danger but also redemption. In the Ming dynasty play Peony Pavilion (Mudanting 牡丹亭) by Tang Xianzu 汤显祖 (1550-1616), the image that the heroine Du Liniang 杜丽娘 paints of herself as she is wasting away from lovesickness is the talisman that will rescue her from death. Thin and frail, longing for the image of a young scholar she has seen only in her dreams, she is determined to leave behind an image of herself in healthier times. After she dies, the same scholar finds this self-portrait and after much longing and dreaming, calls her back from the dead, finding her alive in her coffin. ${ }^{23}$

In both of these stories, the act of representation is a displacement which allows a kind of slippage through space and time. The making of an image implies the room between duplication and duplicity; between preserving an image, and the sacrifice of its object. But if part of the image is in the making, its power is also in the looking. If "Peony Pavilion" has a happy, supernatural ending, it is because Du Liniang's portrait finds exactly the audience it was looking for-the very scholar whose image has appeared to her in a dream.

In "Peony Pavilion", audience is the difference between a painting lost to lecherous eyes, or a painting that reaches out from death to life, love, and rebirth. In his work

${ }^{22}$ Richard Vinograd, Boundaries of the Self: Chinese Portraits, 1600-1900. Cambridge: Cambridge University Press, 1992. p.16.

${ }^{23}$ Vinograd, p.18. 
on visuality in Ming China, Craig Clunas argues that it might be the viewer of the painting who gives meaning to the work. He asks, "might it not be the case equally that visuality in China is about the centering of seeing in the seer?" He argues that the difference between Chinese and Western painting might not be in the painting itself, but in the seeing, that "seeing" might be about "the production of knowing subjects". ${ }^{24}$

The power and danger inherent in a picture, then, is also in its uncontrolled reception, unmediated by educated men (not women) who know how to read the picture "correctly". Clunas has written about the deep suspicion of mimetic pictorial representation running through traditional Chinese art criticism. ${ }^{25}$ Certain types of imagery, religious or pornographic, were deemed dangerous to the social order, because common people could not be counted upon to see a representation for what it was, and might mistake it for reality. ${ }^{26}$

In the Qing dynasty masterpiece Dream of the Red Chamber (Hongloumeng 红楼梦) by Cao Xueqin 曹雪芹(1715?-63) the problematic of representation-of distinguishing between what is real and what is false--is implicit from the very beginning of the novel..$^{27}$ Dream and imagery, both pictorial and literary, inhabit both the content and the structure of the work. The story itself is written of a piece, predestined in the relationship between a stone rejected by the goddess Panyu, and a small flower. The text is written on the massive slab, no good for mythic construction but fine as surface for entertaining fiction, then shrunk to the size of a talisman hung around the neck of the novel's hero Jia Baoyu 贾宝玉. The main female characters, the "Twelve Beauties of Jinling" whose fates are mapped out in the "Dream of Golden Days" song cycle have only a short time in which the confluence of their youth and beauty may bloom. ${ }^{28}$ The central tragedy of the novel is that the moment must be both celebrated and mourned even as it is being lived. The experience of time is amplified-through representation. In the exchanges of poetry and painted handkerchiefs, the thickly decorated furnishings and clothes, the mirrors of longing, the realism of portraiture, games of theatre, the misunderstanding and misreadings of emotion and conversation, in the existence of the very narrative

${ }^{24}$ Craig Clunas, Pictures and Visuality in Early Modern China. Princeton: Princeton University Press, 1997, p. 133. See especially his discussion on "Ways of Looking", pp.111-133.

${ }^{25}$ Clunas, p. 149.

${ }^{26}$ Clunas, p. 158.

${ }^{27}$ Translated as The Story of the Stone by David Hawkes. Vol. I. "The Golden Days", Harmondsworth: Penguin Books, 1973.

${ }^{28}$ See David Hawkes' appendix to his translation, pp. 527-534. 
itself. To determine real from false is perhaps not the point here. To accept that the two may co-exist through the experience of representation, and that life be made richer and more treacherous for it, is.

A hundred years later, we see Dream of the Red Chamber appropriated and recapitulated as one of the major scripts of Shanghai courtesan culture in the late Qing. ${ }^{29}$ In this admittedly more populist reading, courtesans and their patrons played out scenes from the Daguanyuan 大观园 garden, and brothels mimicked the luxurious settings and clothing of the Jia mansion. Prostitutes took the names of the female characters, a burial ground for destitute streetwalkers was named the Flower Cemetery after the famous scene in which Lin Daiyu 林黛玉 buries fallen flower petals. ${ }^{30}$ In the context of late-Qing Shanghai courtesan culture, the novel's imagery completely overshadows its literary subtleties.

The same could be said of the fiction produced in the late-Qing. The quality of courtesan novels is mixed at best. In part this has to do with the conditions of production. The great Ming and mid-Qing novels were produced slowly in private and for an audience of friends-reworked, discussed, and reworked again. The serialized fiction at the end of the nineteenth century was produced on order and to a specific time and length, often with little planning, and catering to a semi-literate audience. Thus, while courtesan imagery reached new heights in the late-Qing, the narratives of courtesan life did not address the meaning or implications of these same images. Instead the text seems simply to rest on the page next to the illustrations. $^{31}$ The narratives are about the political and social transgression of norms and boundaries, on at once extending the space of action out of the courtesan houses and into the streets, and colonizing the brothel into a space of business, culture, and politics. ${ }^{32}$ Although there is abundant description, situating the action squarely in Shanghai, concretely describing the hybrid East-West materiality of courtesan homes, dress and accessories, the nature of depiction itself is not

${ }^{29}$ Yeh, Shanghai Love, see Chapter Three, "Playground Shanghai: Re-enacting the Dream of the Red Chamber", pp. 136-177.

${ }^{30}$ Yeh, p. 236.

${ }^{31}$ See Catherine Vance Yeh, "Creating the Urban Beauty: The Shanghai Courtesan in Late Qing Illustrations" pp. 397-447, in Zeitlin, Judith, Liu, Lydia H., eds., Writing and Materiality in China: Essays in Honor of Patrick Hanan (Harvard -Yenching Institute Monograph Series). Cambridge: Harvard University Press, 2003. See also her chapter six, "The Image of the Shanghai Courtesan in late Qing Illustrated Fiction", in Shanghai Love, pp. 248-303.

32See David Wang Der-wei. Fin-de-Siècle Splendor: Repressed Modernities of Late Qing Fiction, 1849-1911. Stanford: Stanford University Press, 1997. 433 pp. See especially Chapter Two: “Edifying Depravity: The Courtesan Novel". 
questioned. References may be made to photographs or illustrations, but only as artifacts.

In September of 1915, the first issue of New Youth was launched with a call to arms by 36 year-old Chen Duxiu. Sixteen months later, Hu Shi's 胡适 manifesto “Some Tentative Suggestions for the Reform of Chinese Literature" (Wenxue gailiang chuyi 文学改良刍议) appeared. The literary movement and the literature it produced have been extensively studied. For the purposes of this study, it is enough to observe that student intellectuals, given permission to apply themselves to literary work that was perceived as essential to nation- building, had the means to produce work that was exploratory, the result of readings in Western literature, and the serious contemplation of their own environment. Unlike the late-Qing journalists who produced serialized entertainment fiction to order, the May Fourth writers took up the short story form, publishing finished work in literary journals. Few of them lived by writing alone, many had teaching jobs in universities, or editing positions in publishing companies.

It is after the transition from courtesan art to calendar art, and the shift from lateQing popular fiction to May Fourth intellectual fiction, that we find the most interesting writing about the looking at, and making of, female images. Not surprisingly, with some exceptions, the strongest work comes out of Shanghai, the acknowledged centre of Western art studies in China, and also the geographical area with the highest exposure to and concentration of commercial art images. ${ }^{33}$ Philippe Hamon, in writing about the new relationship between image and literature in nineteenth- century French literature, has argued that the abundance of imagery produced by new technologies pushed writers in two directions: first, to localize imagery, situating images firmly within a geographical and then textual context; and second, to move literary developmental work away from the "imitation" of previous literary forms, and to look for models outside of literature, in the representational dynamics of imagery. ${ }^{34}$ If we apply his observations to the Chinese experience, it is possible to see that the first movement, the building of an

${ }^{33}$ Yi Ming 逸明, Minguo Yishu: shimin yu shangyehua de shidai 民国艺术: 市民与商业化的时代. Beijing: Guoji wenhua chuban gongsi, 1995, 147 pp. See especially chapter four, "Youhua, xixuedongjian de xiangzheng" 油画西学东渐的象征 (Oil painting, the phenomenon of western learning going east), and chapter five, “Wanli jingshende fuxing" 万历精神的复兴 (The rebirth of the [Ming dynasty] Wanli spirit) on calendar art, the woodblock prints supported by Lu Xun, and the artistic work of Zheng Zhenyi . See also Sherman Cochran (ed.), Inventing Nanjing Road: Commercial Culture in Shanghai, 19001945. Ithaca: East Asia Program Cornell University, 1999, 252 pp. Also Karl Gerth,: China Made: Consumer Culture and the Creation of the Nation. Cambridge: Harvard University Press, 2003, 445 pp. ${ }^{34}$ Philippe Hamon, Imageries: littérature et image au XIXème siècle. Paris : Jose Corti, 2001. p. 30. 
"iconotope" in which new courtesan imagery is firmly localized in the texts and geography of Shanghai, is already taking place in late nineteenth-century China. It follows the development of mass-production technologies in the treaty-port cities almost simultaneous, but on a much smaller scale, with what is happening in the West. ${ }^{35}$ Secondly, although China too had a literary history built on the "imitation" of previous literary forms, there was also already a tradition of looking to other representational models outside of literature-in the Buddhist discourse in Journey to the West, for example, and again in the Taoist questioning of real and unreal in Dream of the Red Chamber. Yet what can be seen, after the carefully constructed break of the Chinese literary revolution in the 1910s, is a kind of restarting, and the play of representational models is taken up again, reaching its apogee in the 1920s and 1930s, not coincidentally when calendar art also had its strongest presence. Thematically, the stories are most fruitful when grouped around particular spaces-spaces where images are produced and receivedincluding the beauty salon (cosmetics and dress), the street (advertising, observation and demonstration), the store (consumption and choice), and the stage (performance, spectacle, disguise), the journal and magazine (the story, news, the serialization), the nightclub (darkness, the dance, assignations). For this paper, we attempt a preliminary exploration of the atelier.

\section{The Atelier}

\section{TENG GU: “BIHUA” 滕固: 壁画}

Teng Gu (1901-1941), a native of Baoshan (part of present-day Shanghai), was an undergraduate at the Shanghai Arts Institute. In 1921 he went to Japan to study, graduating in 1924 with a degree in literature from Tokyo University. Returning to China, he taught at his alma mater, as well as Nanfang University in Guangzhou and Jinling University in Nanjing. In 1930 he went abroad again, this time to Berlin to study art history, and returned with a doctorate in 1932. Until his early death in 1941, his pursuits were mainly academic and administrative, and he published works in Chinese art history, Chinese painting, traces of European style in the Yuanmingyuan Summer Palace, library science, and, most important for the purposes of this paper, a work on the literature of the Aesthetics movement in

${ }^{35}$ See Yeh's arguments on the localization of Shanghai courtesans images, and the emergence of the city of Shanghai as a character in late-Qing writing in "Creating the Urban Beauty: The Shanghai Courtesan in Late Qing Illustrations" pp. 397-447, in Judith Zeitlin and Lydia H.Liu, eds., Writing and Materiality in China: Essays in Honor of Patrick Hanan (Harvard -Yenching Institute Monograph Series), Cambridge: Harvard University Press, 2003. 
Britain..$^{36}$

Loosely affiliated with the Creation Society, Teng's interests in contemporary art and literature included readings of Oscar Wilde and Théophile Gautier, as well as Tanizaki Junichirô (1886-1965). As co-founder of the literary Sphinx Society, he would have participated in discussions influenced by readings of Baudelaire and Verlaine. ${ }^{37}$ Although we have no precise information on which works by these authors Teng personally read, or in what language, we can guess that he was exposed to the Western writing inundated with imagery -- Baudelaire's evil flowers, perhaps Rosette's boudoir in Gautier's Mademoiselle de Maupin, the studio where Dorian Gray was painted, along with the rotting and corruption of the portrait itself.

Teng's best known stories depict the sexual and creative frustration of Chinese art students living in Tokyo. Shih Shu-mei has suggested that, as in the work of $\mathrm{Yu}$ Dafu 郁达夫, the national intersects with the libidinal, and that in Teng Gu's work, the sexual repression imposed by China's political and military weakness also blocks the flow of artistic creation. ${ }^{38}$ A reading of "Mural" (Bihua, 1922) also reveals that it is the act of Western representation that intensifies and complicates the dilemma of these students.

The story opens with a visit the protagonist Cui Taishi 崔太始 makes to his friend $\mathrm{T}^{\prime}$ s rooms. Cui has been in Tokyo five years and is in his final year of art school. Although he never managed to finish anything, he is commonly acknowledged by his peers to be the most gifted and promising among them. This year, he has moved to the Ginza, to a room where the light is good, and hired a model to work on his graduation piece. He reports he is making good progress. But the reason for his visit is literary:

“'T, I have something important to tell you, how about you write a poem for me, to help me vent a little, what do you think?' He nodded, his brow creased, released a puff of cigarette smoke and looked at $\mathrm{T}$.

'What do you mean! I write poems when they come from my own feelings,

${ }^{36}$ Gao Yuanbao, "Daoyan" (Introduction), in Teng Gu, Teng Gu xiaoshuo quanpian 滕固小说全篇, Shanghai: Xuelin chubanshe, 1997, p.1. See also a brief discussion of Teng Gu in Shih Shu-mei, The Lure of the Modern: Writing Modernism in Semicolonial China, 1917-1937. Berkeley: University of California Press, 2001, pp. 125-127.

${ }^{37}$ Shih Shu-mei, The Lure of the Modern, p. 125-126.

${ }^{38}$ Shih Shu-mei, p.126. 
when I have something to say. How would I know what you're feeling?'"39

“' $\mathrm{T}$ 君, 我倒有一重心事告你, 你替我做首诗发泄一下, 怎么样? ’ 他摇摇头, 眉目都皱在一块, 弹去烟灰, 向 T君说。

‘那怎能办到! 我做诗都是自动的, 自己感触的, 自己要说的。你的心事我何从 知道? '”

Cui goes on to express his indignation at having been ignored by a group of young Japanese girl students handing out pamphlets in a school demonstration. It is the kind of story everyone has heard from him. T tells him to calm down, after all, Cui is married and with a child. Cui is indignant, protesting that both wife and child have been foisted on him by feudal circumstances: " T! You are an intelligent person, and not like the others. If you start to criticize me too, I really have no-one to turn to." He was gasping for breath now, and was on the verge of tears." $(\cdots \cdots \cdot$ 君! 你是聪明人, 我不以一般朋友看待你, 你也苛责我, 我真没有地方告诉了 。”他说了，便断断续续的一呼一吸，他不禁滴下了一场眼泪。） ${ }^{40}$

Cui has been working at his painting for five years, but when he needs to express strong emotion, he turns to poetry - poetry that he must ask someone else to write.

Cui is attracted to most of the women with whom he comes into contact, but has no idea how to read their reactions. When his professor visits Tokyo from China, he is smitten with the professor's daughter Nanbei 南白, a gifted artist of traditional painting in her own right. Interestingly, she is the only artist who displays finished work in the story. At her father's request the students band together to put on an exhibition, one approaches the Japanese painter's union for permission, another numbers the paintings, Cui himself arranges the space, another two assemble the catalogues. ${ }^{41}$ The show is a success, the Japanese press even shows up, and $\mathrm{T}$ serves as translator for the professor. Cui is infatuated with Nanbei, thanking her for the few paintings she has given him, and sure that they contain special messages for him.

The next time T meets Cui, it is a month later, at the end of cherry blossom viewing season. Cui is walking through the park with his painting kit. He complains that he has had no word at all from Nanbei, who instead is writing long letters to another

\footnotetext{
${ }^{39} \mathrm{Teng} \mathrm{Gu}$, Teng Gu xiaoshuo quanpian, pp.44-45.

${ }^{40}$ Teng Gu, p.45.

${ }^{41}$ Teng Gu, p.47.
} 
of their fellow students. He also admits that he has given up on his thesis, having fired the model who has refused his advances and moreover preferred the attentions of his studio-mate. T convinces him to try again, and Cui agrees. After another month, $\mathrm{T}$ visits the the rooms of $\mathrm{S}$, with whom Cui is sharing the new model. In the elegantly appointed 8-tatami mat space, $\mathrm{T}$ watches them paint:

\begin{abstract}
There was a girl dressed in a negligee, revealing a smooth snow-white breast: she was sitting sideways in a cane chair, her eyes still and barely blinking. Cui and $\mathrm{S}$ moved back a few steps, set up their easels, and concentrated on mixing the colors, moved in to look more closely, then began to paint. ${ }^{42}$

……只见一位姑娘披了寝衣。露出上身雪白的肌体乳房：斜靠在籐椅上，目不 他瞬的镇静着。崔太始与 $S$ 君离开几步, 装了画架, 一心一意地调了颜色, 进退 瞄视，然后涂上颜色。
\end{abstract}

At the end of the session, the model asks about the negligee. Cui replies that it is the latest fashion from Paris, and very expensive. The model asks to keep it, and Cui agrees, saying that he will buy a new one for their work. Soon after that, $\mathrm{T}$ receives a note from Cui, asking him to accompany him and the model to the movie theatre, but once he gets to the studio, he finds that the model has changed her mind. The two men leave, but out on the street they see her again, this time walking hand in hand with Cui's painting partner S. Cui is beside himself.

The next day, $\mathrm{T}$ receives a visit from Cui's older relative who delivers an English language paper with a strange note written on it:' "T, write the contents of my heart into a poem! Not another of my friends knows my heart, but you really know me!“ It was signed, “Taishi's last note.” (“T兄: 你把我的心事做一首诗罢! 没有一 个朋友知我的心，你是真知我者！太始留笔。” ) 43

The note appears to be written with a fingernail, not a pen, and in the color of blood. The relative reports that Cui is in the hospital, after drinking too much and vomiting blood in a restaurant banquet room. The two men go back to the room, and find a couch stained with blood, and a mural painted in blood on the wall behind it. Looking closely, they can make out the figure of a man on the floor, and the figure of a woman dancing on his belly. The title painted next to it reads, "Cui Taishi's graduate thesis".

${ }^{42}$ Teng Gu, p. 53.

${ }^{43}$ Teng Gu, p. 55. 
Teng Gu's vision of the artist is an early one. The artist is portrayed as a victim of his own desires, but also of his confusion over what his art is for and where its limits lie. Cui continually confuses the living and breathing model with the image he is painting, mistaking the passivity of the posing girl with the acceptance of sexual overtures, and the act of representation with the act of conquest. His insatiable infatuation with every woman he passes on the street can be read as the artist's eye trying to entrap and appropriate every beautiful object it sees. The intriguing figure of the girl artist is similarly reduced, as Cui mistakes the paintings she gives him for secret messages of romantic complicity; being traditional paintings, Cui assumes they can express emotion. Twice Cui asks $\mathrm{T}$ to write his feelings for him in a poem, the second time, after he has used his life's blood to draw the most primitive expression of his dilemma, a man destroyed by the desire embodied in a dancing woman. But he is also an artist destroyed by a representational dynamic he can neither understand nor control. He scrawls his last pleading note on an English newspaper, erasing the Western words and the news -the most basic expression of modernity -- they transmit.

In the art student world of Tokyo, the atelier is a small tatami room, shared between two students and a model, and a reflection of each character's neurosis -- a place of self-creation, but also of self-destruction. As the education of Western art developed in China, depictions of the atelier evolved accordingly.

\section{DING LING: “MENG KE” 丁玲：梦可}

In the autumn of 1926, a group of young students in Beijing formed a new literary group, the No Need Society (Wuxu she 无须需社). With no need of pity, patronage, or gifts, the group also rejected any kind of constitution, and simply requested that its members write. They put together a book that was never published, but partly serialized in the supplement (fukan 副刊) of the World Journal (Shijie ribao 世界日报 ).society. The members of the group were unknown. Without a star like the Threads of Talk group (Yusi she 语丝社) had in writer Lu Xun 鲁迅, or the Crescent Moon Society (Xinyue she 新月社) had in poet Xu Zhimo 徐志摩, their project was at a standstill. With no money coming in, one of the members Jiang Bingzhi 蒋冰之 informed her companion writer Hu Yebin 胡也频 that she was off to Shanghai to work in the movies. Although her friends were writers, Jiang's own training had been in art and music. In Beijing she had studied oil painting. Unable to gain entrance to an academy, she took lessons at a private studio, painting still lifes and 
sculptures of the Venus di Milo.44 But her entry into the world of the cinema would be through literature. She contacted playwright and screenwriter Hong Shen 洪深 who agreed to write her an introduction to the Mingxing 明星 Studios in Shanghai. Tian Han 田汉, another playwright, helped her get an audition, and got his friends to put her in a fancy cheongsam and photograph her in a seductive pose that she found exceedingly vulgar. At the studio, she was overwhelmed by the activity and the different types of actors on call. Which type would she be? She resented the stare of the camera and the glare of the lights. Apparently, she refused the three year contract that was offered..$^{45}$

A year later, in December of 1927, Jiang would incorporate this experience in her first published short story, under the pen name of Ding Ling (1904-1986). The story, called "Meng Ke" (the phonetic equivalent of the French "mon coeur"), appeared in Short Story Monthly (Xiaoshuo Yuebao 小说月报) under the editorship of Mao Dun. The story opens at the beginning of the school year, in Shanghai, on the sports ground of a middle school where a group of young girls are playing volleyball. Suddenly one of them shouts, "Red nose, it's red nose!" One of their male teachers, the one with the offending probiscus, walks quickly out of classroom 8 and into the teachers' lounge. The players desert the game to see what has happened, the scene of sporting vigor quickly shifts to a studio classroom. A group of students stand whispering. Next to some drapery is a low bench covered in redvelvet, and on the velvet sits a model, half dressed in a transparent robe, crying. Near the wall, standing at No. 3 easel, is another girl, a nülang 女郎 maiden, dressed in black--the eponymous Meng Ke.

"Silently, with large brash eyes, she coldly stared at the people in the room. She slowly batted a pair of thick lush eyelashes, and began to move her body, straight as a statue's, walking over to lift the model's face up with both hands, staring closely at her, to see the half-nude girl's tears falling one large teardrop after another." 46

“......默默的愣着那对大眼, 冷冷的注视着室内所有的人。等到当她慢慢的把那 一排 浓密的睫毛一盖下, 就开始移动她那直立得象雕像的身躯, 走过去捧起 那模特儿的头来, 紧紧的瞅着, 于是那半裸体女子的眼泪更大颗大颗的在流。”

Meng Ke, having caught the teacher harassing the model before class, tells the girl to stop crying and slowly manages to dress the girl and usher her out of the studio.

\footnotetext{
${ }^{44}$ Zhou Liangpei 周良沛, Ding Ling zhuan 丁玲传, Beijing: Shiyue wenyi chubanshe, 1993, p.135. ${ }^{45}$ Zhou Liangpei, pp.159-162.

${ }^{46}$ Ding Ling, Ding Ling duanpian xiaoshuo xuan 丁玲短篇小说选, Vol. 1. Beijing: Renmin wenxue chubanshe, 1981.p.2.
} 
On the way out, a fellow classmate stops them, announcing he wants to call a meeting to discuss the teacher's behavior. Meng Ke tells the student to go ahead with the meeting, but she wants nothing more to do with the school and leaves.

"Afterward, things went back to their customary quiet. Only the school did not see Meng Ke again. The red-nosed teacher continued to walk along the corridor. After about two months, another girl was hired who came twice a week at a salary of 20 yuan a month, to replace the other model." 47

“以后呢, 依旧是非常平静的又过下来了。只学校里再没见着梦珂的影子。红鼻 子先生还是照样红起一个鼻子在走廊上蹬去又蹬来。直过了两个朋, 才又另雇 得一个每来两次, 一月拿二十块钱的姑娘, 是代替那已许久不曾来的, 上一个 模特儿的职务。”

Meng Ke's mother died in childbirth. Her father is a reformed rake, a literary dilettante and connoisseur of Shanghai courtesans in his youth who returned home chastened after an official career ended in a case of sexual scandal. His daughter has been raised in the care of servants and the occasional arts instruction of her father. Preternaturally beautiful, she has grown up "like a orchid, quiveringly lush, slender and graceful, a snow-white face. From her first baby-steps, when her narrow long eyebrows would knit, or those thick luxuriant eyelashes would blink, there would be a long sigh from those watching." 48 ……长得象一枝兰花, 颤蓬蓬的 , 瘦伶伶的, 面孔雪白。天然第一步学会的, 便是把那细长细长的眉尖一歳一歳, 或 是把那生有浓密睫毛的眼睑一阒下, 就长声的叹息起来。

The scene in the atelier is the break that marks the start of Meng Ke's search for her own place in the world. The sobbing girl stripped of clothing and power is a spectre which haunts her quest.

Leaving school, Meng Ke stays first with an old school friend and then with wealthy relations. Her aunt, a woman in her forties, is running to fat, but made up to look more youthful. "Her hair was already thinning at the top, but she rubbed oil into it and from far away it wasn't noticeable. She wore it in two rolls on either side of her face, covering the ears. She was squeezed into a tight fitting long robe, and when she walked there was a rhythmic rustling sound." 49 头顶上已脱了一小撮头 发, 但搽上油, 远看也就看不出什么, 两边是拢成骨头形, 盖住一大半耳朵。拖着一 幅齐脚的缎子长裙, 走路时便会发出一种綷綷沙沙的响声。A fashion devotee, she has surrounded herself with young people, various nieces and nephews and their

${ }^{47}$ Ding Ling, p.3.

${ }^{48}$ Ding Ling, p.4.

${ }^{49}$ Ding Ling, p.10. 
friends, all living in the same compound. These include her younger son, Meng Ke's cousin, Xiao Song 晓松, just returned from his studies in France, who soon becomes her close friend and confidante.

Meng Ke is uncomfortable in her new surroundings. Looking out onto the city from her window: "The sun glinting on the windows across the way, the sound of car horns", she compares it with the purity of her childhood in the countryside when she could be intimate and friendly with the people in a natural way. She thinks of how she has to force herself to fit in now, and her eyes moisten with shame. ${ }^{50}$ But through the next weeks and months, Meng Ke becomes more used to her comforts. Her aunt presents her with a new dress, "a coffee-colored lined robe of New York silk." Afraid of appearing ungrateful, she puts it on, and discovers that:

"...because she was so unused to the tightness of the narrow robe, the panels kept getting caught behind her legs, and that soft slipperiness of the fabric was so shiny it made her shy and stiff to be around anybody. Especially when she forgot and tried to walk more quickly, the pearl border would crash into the side of a table or a doorframe, and she would hurriedly have to correct her way of walking, worried about whether she had broken off another pearl."51

“......虽说她一走路便感觉到, 十分不适意那窒窄小的袍缘, 悉率着脚背, 便是 那质料的柔滑, 光泽也使她在人前时会害羞得举止倒呆板起来。尤其当她忘记 了快走时, 那珠边很鲁莽的就碰在桌边或门缘, 她又得急速地改变那走路的姿 势，心就去惦记着那珠子总得又碰碎了几颗。”

Tan Ming 澹明, a friend of Xiao Song who is teaching at an art academy, is delighted that Meng Ke is an art student. Attracted by her bright eyes and straight shoulders, he presents her with a few reproductions of painted nudes and landscapes he has brought back with him from France and which she places respectfully on her desk to peruse at her leisure. In the evenings, she reads novels given to her by Xiao Song, or listens to Xiao Song and Tan Ming talk about Paris. She loves hearing about the museums, parks, theatres and restaurants, and entertains fantasies of being a waitress in a Parisian café..$^{52}$

With their encouragement, she begins to study oil painting, Tan Ming brings over paints and canvas:

"She would often spend the whole day painting copies of the paintings she

\footnotetext{
${ }^{50}$ Ding Ling, p. 12.

${ }^{51}$ Ding Ling, p.13.

${ }^{52}$ Ding Ling, p.13
} 
loved. Or she would paint the azure sky from her window, the bamboo across the way, the tree growing at the corner of the building...finally, after spending four hours on one painting, she had a scene from her window, it was a corner of the garden, with the grass pavilion from the back moved into the center of the lilac bushes, and in the lawn in front, Lili [Xiao Song's niece], was playing with a ball. Looking at it, she was pleased, and gave it to [Lili's mother] as a gift." ${ }^{\prime 53}$

“常常整天躲在房子里照着那些自己所爱的几张画模仿着。或涂着那从窗户里看 见的蓝的天空, 对门的竹篱, 楼角上管起的树...... 末后, 费了四个钟头才画好 一张, 也是从窗户里望见的景致, 是园里的一角, 在那丁香花从中搬来了屋后 那草亭, 前面的草坪中, 丽丽正在玩一个大球。自己看后深得还满意, 于是就 去送给表姊。”

Meng Ke begins to work harder at painting, no longer content to stay inside her room painting scenes from her window or, sometimes, her own hand or foot. She moves outdoors, supplied with collapsible easel, and a matching three-legged stool. Xiao Song and Tan Ming accompany her on these outings, driving out to the countryside for painting and a picnic of canned meat, fruit, bread and even wine. Often they talk so much that the paints stay in their case. At such times, Meng Ke feels nurtured and protected, and her behavior becomes almost childlike.

In the course of the story, Meng Ke is exposed to various public venus where women in the audience are placed on view. There is the New World entertainment center where Meng Ke and her friends are oggled by the men, the Carleton movie theatre where during the intermission the gaze (yanguang 眼光) of both men and women is by turns hungry, calculating, and greedy. An old school friend, Ya Nan, also staying in the compound, takes her to an anarchist meeting, in filthy rooms where the girls shock Meng Ke by their casual behavior, shaking hands and kissing the boys in greeting. One of them, "Our Miss Sophia", invites her to come to following week's meeting, but Meng Ke desires only to remove herself as rapidly as possible.

No matter where Meng Ke is, she cannot escape the gaze. One evening she plays a chess game against Tan Ming, with Xiao Song as her advisor:

"She sat across from Dan Ming. Xiao Song was sitting next to her, leaning against the back of her chair, insisting on being her advisor. From time to time he would reach over her shoulder to take the chess pieces. When his body leaned over, his soft breath would warm the back of her neck, so she turned

${ }^{53}$ Ding Ling, p.15. 
her face away. Then Xiao Song could see the shadow of her thick lashes on the curve of her cheek, and turned his face toward her, thinking to look more closely at the dark eye in the shadow of the lamp, and moved his chair closer. Meng Ke was concentrating totally on her pieces on the chessboard, and did not notice that across from here there was also a pair of eyes examining her slender fingers, the evenly filed peach colored nails tipping the pair of snow white hands. Her skin seemed to be translucent. Beneath the clear surface, could be distinguished the hair fine of her pulse and veins." 54

“她是正坐在澹明的对面, 晓淞是斜靠拢她的椅背边坐着, 强要替她当顾问, 时 时把手从她的臂上伸出抢棋子。当身躯一向前倾去时, 微弱的呼吸便使她后颈 感到温温的微痒，于是把脸偏过去。晓淞便又可以看到她那眼睫毛的一排阴影 直拖到鼻梁上, 于是也偏过脸去，想细看那灯影下的黑眼珠，并把椅子又移拢 去。梦珂却一心一意在盘算自己的棋, 也没留心到对面还有一双眼睛在审视她 纤长的手指，几个修得齐齐的透着嫩红的指甲祄在一双雪白的手上。皮肤也旬 是透明的一样。荣净的里面, 隐隐分辨出许多一丝一丝的紫色脉纹, 和细细的 几缕青筋。”

On another occasion, Xiao Song invites his cousin to the movie theatre and then watches her change in her own room from the terrace:

"[Xiao Song] sat on the low stool and watched Meng Ke dress. Under her short black silk petticoat peeped out a pair of rounded calves, from beneath the thin silk stockings shone fine white flesh. It seemed as if his gaze rested on this leg long enough, he would see something more." 55

“表哥坐在一个矮発上看梦珂穿衣。在短短的黑绸襍裙下露出一双圆圆的小腿, 从薄丝袜里透出那细白的肉, 眼光于是便深深的落在这腿上, 好象还另外看见 了一些别的东西。”

During the winter, Meng Ke drops painting and takes up the study of French. Another cousin's wife draws her into a discussion of modern girls in China. They discuss old women's magazine articles, pondering whether to be a prostitute is any better or worse than being a wife. By the spring, despite her reservations, still afraid of growing up into an unknown future, Meng Ke is slowly turning toward Xiao Song, who is courting her slowly but surely.

The interlude comes to an abrupt end. As a practical joke Meng Ke is brought to a hotel where she and the rest of the group confront Xiao Song in a hotel room where he has been staying with his married mistress. Meng Ke is gone the next day, leaving an excrutiatingly polite thank-you letter for her aunt.

${ }^{54}$ Ding Ling, p. 16.

${ }^{55}$ Ding Ling, p.18. 
Throughout her stay in the compound, Meng Ke has been subjected to the gaze of strangers and friends. She rarely dares to lift her head up and look back, with one important exception-when she accepts Xiao Song's invitation to see the film Camille. ${ }^{56}$ Meng Ke, who has already read the Alexandre Dumas fils novel La Dame aux Camélias in translation, is curious. The theatre itself is packed, a public but enclosed space so densely intersected with sightlines that the social hunt and its desires are almost palpable. But when the lights go down, it is Meng Ke who is transfixed:

"As soon as the camera focused on the woman in the long black skirt standing at the top of the stairs, Meng Ke's gaze was fixed on the screen, remembering the book she had read on one hand, and on the other completely accepting the actress's embodiment of the character Camille. Moreover, she felt her tragic pain, as if she herself shared the same fate." ${ }^{57}$

“当刚映到那拖黑色长裙的女人出现在石阶梯上时, 梦珂便专精注神的把眼光紧 钉在幕上, 一边体会着从前所看的那本小说, 一边就真真把那化向的女伶认作 茶花女，并且还去分担那悲痛，象自己也是陷在同一命运中似的。”

After the intermission, Meng Ke is once again caught up in the story, but leaves before the end when the scenes have become too painful to watch and she is already crying. That evening, she lies in bed thinking about the film:

"...she simply loved the actress. The love story and the plot were over quickly, and what remained was simply the lone star, the memory of the actress's frown, her smile, and a kind of tragic life experience that seemed to be the actress's own. She tried to remember her name, but couldn't think of it. She thought of going downstairs to ask Cousin, but was afraid of waking the others. " 58

“......简直是爱上那幕上的女伶了。那些剧情和许多别的配置都忽略过去, 单单 只零星的记牢了那女伶的一頻一笑, 还和那仿仿佛佛的一种可悲的身世, 这身 世也只是那女伶的。于是便又去记忆那女伶的名字, 但总记不起, 想下楼去问 表哥, 又怕别人已睡觉, 只好留在明天再打听,

Too excited to sleep, Meng Ke gets up and plays a few rounds of domino solitaire, and finally writes a poem in her journal:

${ }^{56}$ Likely to have been the 1926 filmic version, of the novel and play, with Norma Talmadge in the starring role.

${ }^{57}$ Ding Ling, p.19.

${ }^{58}$ Ding Ling, p. 21. 
"I care nothing for glory,

But cannot sleep. In the deep of this night,

It is because I think of her painful life..."59

“我淡漠一切荣华, 却无能安睡, 在这深夜, 是为细想到她那可伤的身世。”

Meng Ke too, it seems, can desire and love an image. But her reaction is different from her male counterparts. Her response is not to possess, but to identify with and to become. When her illusions about Xiao Song are shattered, she looks to her remaining ones, and resolves to apply for a job as an actress at the Yuanyue Drama Society. The company takes her on almost immediately, first subjecting her to a painful scrutiny to determine what type of character she should play:

"Finally he forced her to accede to an awkward request: she silently lifted both hands and lifted her hair away from her temples, revealing a rounded forehead and two delicately sculpted ears. At that moment, her pain-no, it was as if she was being forced to tears. But she was accepted. He praised her, flattered her, encouraged her, he was willing to help her, the point was that he wanted her to know that he could make her a star." 60

“最后还使人不得不允许了他如此一个令人不快的要求：她无声的举起一又手去 勒上两髸及额上的短发, 显出那圆圆的额头并两个小小的玲珑的耳垂给人审视 。这时候, 她伤心——不, 完全是受逼迫得哭一样。但她却很受欢迎了。他又 赞美她, 又恭维她, 又鼓励她, 又帮助她, 意思是要她知道, 他总可以使她在 上海成为一个很出众的明星。”

The final scenes of the story show Meng Ke in the eye of the stage and the camera, being made up and dressed, forced to move around and act to order. She has entered into a world where appearance is contrived and emotion artificial:

"Today, no matter whether in the reception room, in offices, the cafeteria, on the set, in the make-up room...everywhere she went, there was the vulgar and improper language of the actors, actresses and directors, or the screams of women after being pinched in the ass, and all sorts of mutual glances [yanguang] between them--everyone did as they pleased, laughing, happily chatting, playing. It was only her-she was surprised, suspicious, as if she herself had become like a prostitute to bear the disrespectful gazes of this place." 61

“这天, 无论在会客室, 办公室, 餐厅, 拍影场, 化装室......凡是她所饱领的, 便是那男女演员或导演间的粗鄙的俏皮话，或是当那大腿上被扭后发出的细小

${ }^{59}$ Ding Ling, p. 37

${ }^{60}$ Ding Ling, p.38.

${ }^{61}$ Ding Ling, p.40. 
的叫声, 以及种种互相传递的眼光, 谁也都是那样自如的, 嬉笑的, 快乐的谈 着, 玩着。只有她, 只有她惊诧, 怀疑, 象自己也变成妓女似的在这儿任那些 毫不尊重的眼光去观览了。”

On her way to her first take, she looks in the full length mirror and sees that the makeup man has made her up to look exactly like the streetwalkers on Fuzhou Road. Playing a minor role this time, she takes her place on the set while the lead actress chats happily with the crew. The director yells "Action!" and at that moment there is a slight thump. Everyone turns to discover that the new actress has fainted dead away.

In the final passages of the story, we learn that Meng Ke, now known as Lin Lang, has become a star who specializes in silent suffering, one who, it is hoped, "can, through her body, bring about the satisfaction of each person's desires, or let them derive a bit of happiness from these desires." 62

Beginning with the atelier, and closing with the movie studio, it is tempting to think that Ding Ling leaves Meng Ke worse off than when she finds her, finally succumbing to the imperatives of the insistent subjugating male gaze that defines pre-1949 Shanghai culture. Yet, it is obvious that once she leaves the family compound, she increases the range of her own gaze. She "loves" the actress in Camille, and she chooses to be like her, including assuming the pain that she sees in the woman's performance.

The leap she makes in going to the theatre is only surprising in its courage. The only other time she behaves so straightforwardly is when she protects the artist's model and marches out of the school with her. This time, she walks directly into the gaze of the camera.

When she meets with the director, she fixes her large eyes on him, assessing every detail of his appearance:

"On that cleanly shaven face, were very sensitive nostrils; between the small red lips, a row of shiny white teeth could be seen when he spoke. The left hand was fine and smooth, fiddling with the chain of his watch fob. Hmm, the necktie pin was very nice! She stared at this person unwaveringly, thinking about other things, and so didn't hear clearly what he was saying. Only when

${ }^{62}$ Ding Ling, p.42. 
she saw that his gaze on her own face seemed to expect her to say something, she then began to speak slowly about why she had come. She began in a roundabout way, gradually she began to get braver and finally said,

'...Now of course I don't have to explain so much about myself, later you will understand it's because of my inner conflicts and needs. I believe I won't disappoint you.'" 63

“......在那一张刮得干干净净的脸上, 有个很会扇动的鼻孔; 在小小的红嘴唇里 , 说话中不时露出一排雪白的牙齿。左手是那样的细淢, 随意的在玩弄着胸前 的表链。呵, 领结上的那颗别针, 还那样讲究呢! 她不转眼的望着这人, 心便 怀疑到这人以外的一些东西, 竟未曾把对面那人所说的一些客套话听清楚, 直 望见那一道同时也注视到自己脸上的眼光, 是现着在期待她说话的神情, 于是 她才迟迟疑疑的开始来说明她来此地的希望。先是绕着大弯子讲, 渐渐也就放 大了胆, 最后还这样说:

“现在我当然可以不必多解释我自己, 将来你总会明白的, 因了我内存的冲动和 需要。我相信我不会使你们太失望......'”

Having made an appointment for an audition the next day, Meng Ke goes home to prepare. That night she sits in front of the mirror, gazing (wangjian 望见) at her own image, and her soft fingertips:

"She brought them together and polished them on her chest, showing off. By now she was already rapt in hope, forgetting the day's problems. She threw an a charming glance (yanguang) at the mirror, then a leisurely smile, then began to act by herself. This performance didn't have a particular story or setting, it was the many different expressions she made in front of that eight inch high mirror. At the beginning she seemed to be pretending to be a singsong or dancing girl, so she put on affected airs for the person in the mirror, raising her eyebrows and looking at the ceiling. Other times she had the dignity and luxury of a noblewoman...but the noblewoman and dancing girl's fates were all extremely unlucky, so that in the end those two eyes staring straight ahead at the mirror began to fill with tears. She truly cried, and then afterward laughed contentedly, wiping her eyes with a handkerchief: 'Who would have thought it? I didn't know myself I could cry like that!'"64

“......便又互相拿来在胸前抚摩着, 玩弄着。这时她是已被一种希望牵引着, 她 忘了日间所感得的不快。于是她又向镜里投去一个妩媚的眼光, 并一种佚情的 微笑, 然后开始独自表演了。这表演是并没有设好一种故事或背景的, 只是她 一人坐在桌子前向着有八寸高的一面镜子做着许多不同的表情。最初她似乎是 在装着一个歌女或舞女, 所以她尽向着那镜里的人装腔作态, 扬眉飘目的。有

${ }^{63}$ Ding Ling, p.37.

${ }^{64}$ Ding Ling, pp.38-39. 
时又象是一种爵夫人的尊严, 华贵......但这爵夫人, 这舞女的命运都是极其不

幸, 所以最后在那一对张大着凝视着前方的眼里, 饱饱的含满一眶泪水。真的

, 并且哭了, 然而她却非常得意的笑着拿手绢去擦干她的眼泪: '这真出乎意料

了。我自己都不知道我竟哭得出来! '”

Of course, Meng Ke has already cried bitterly over the discovery of Xiao Song's affair--what she means is that she didn't know she could cry like that and not mean it. Meng Ke is becoming less afraid to look because she has learned, like Ding Ling herself, to make stories, to play with representations. She has tried painting, reading, learning French, playing chess, watching movies--all mediums for building alternate representations and images. In the end, she turns herself into an instrument of representation. She will be model and artist, prostitute and client, be looked at and look.

In her deployment of the atelier space, Ding Ling is exploring the spectacle of being a woman. There is the school room where the painter's model is humiliated, the private contemplative space where Meng Ke does her first experimentation with oils, the limitless boundaries of the outdoors (where little or no painting happens), the small space of the "eight-inch high mirror" where the fledgling actress practices her faces, and the cavernous sound stage of the movie studio. Similarly, the constructions of femininity--as nude, "mo-deng" 摩登 girl, virginal victim, as creator/artist, as actress, are dissected into their respective parts-flesh under gossamer, the constriction of the cheongsam, the retreat into childhood memories and behaviors, the application of paint on canvas, the painting of cosmetics, lighting and feigned expression on the body.

Finally, there is one other space-the textual one. When men focus on the contours of Meng Ke's beautiful face, they do so at Ding Ling's behest, for the reader's consumption. Ding Ling the writer has made herself the eye and the pen. She will look, and she will be looked at. Her next story, the famous construction of a woman's psyche as a textual space, "Diary of Miss Sophie" (Shafei nüshi de riji, 1927), confirms that destiny. For the rest of her life she would be identified with the character.

For Ding Ling, representation is not emotion. Representation is the gaze, and most usually, a gaze directed at women. What she gives us is an unfolding catalogue of defense strategies. Meng Ke finally turns to face the gaze, to direct it at others and beam it on herself. The stare she trains on the director is a distinctly male one, reducing him to a series of soft sensual surfaces, and she is not even listening to him. This is Ding Ling's secret joke. She dares to apply the constructions of 
femininity she builds to anyone.

\section{ZHANG HENSHUI: THE ART PALACE 张恨水：艺术之宫}

In the spring of 1930, Zhang Henshui (1895-1967), already an established writer of serialized fiction, began a new work, Aixiao yinyuan 啼笑姻缘 (A Match for Tears and Laughter), about a young student in Beijing and his relationships with two women; the fashionable westernized Lina, and the traditional street artist Fengxi. The story appeared in the supplement of the newspaper Xinwenbao 新闻报, and ran through 22 chapters, ending in the autumn of that same year, and published in book form a few months later. Even before the final installment, it was clear that Zhang had an enormous hit on his hands, and the story was turned successively into popular pingtan ballads, a stage drama, and a film. ${ }^{65}$

In 1931, Zhang returned with his family to Beijing and, with the money he had earned from the novel as capital, helped found the North China Arts School (Huabei meishu zhuanmen xuexiao 华北美术专门学校). Because of his reputation he was named president, and took charge of the Chinese classical literature class as well as courses in creative writing. Zhang was himself an enthusiastic painter of traditional landscapes, and recruited famous friends to teach painting, including Qi Baishi 齐白石, Wang Mengbai 王梦白 and Li Kuchan 李苦禅. Liu Bannong 刘半 农, a well known experimental poet and essayist, was named as a trustee. The school had an enrollment of more than 200 students, and the curriculum included traditional painting, western-style painting, and art pedagogy.66

According to his son Zhang $\mathrm{Wu}$ 张伍, Zhang Henshui made sure the tuition fees at the Beihua meizhuan were low so that poor students who loved art would have the opportunity to gain entry into the "art palace" previously open only to the rich. The school, situated on Dong Si Road, was an old princely mansion featuring a series of courtyards. Zhang, whose rooms at the back had the best view of the gardens, often spent the night there writing. In his free time, he audited classes in traditional painting, and most enjoyed working on collaborative works with the other professors. ${ }^{67}$

\footnotetext{
${ }^{65}$ Yang Yi 杨义, ed. Zhang Henshui mingzuo xinshang 张恨水名作欣赏. Beijing: Zhongguo heping chubanshe, 1996, pp. 114-115.

${ }^{66}$ Zhang Wu 张伍, Yi fuqin Zhang Henshui xiansheng 忆父亲张恨水先生. Beijing: Shiyue wenyi chubanshe, 1995, pp.159.

${ }^{67 Z h a n g ~ W u, ~ p . ~} 160$.
} 
In 1935, in the middle of the Sino-Japanese war, Zhang was forced to leave Beijing, according to his son, after the Japanese complained to General Zhang Xueliang 张 学良 about the writer's anti-Japanese statements. ${ }^{68}$ Back in Shanghai, Zhang then took a job with the new periodical Libao 立报, as editor of the fukan (supplement). As part of his duties, he began a new serialized novel Yishuzhigong 艺术之宫 (The Art Palace) in the opening issue that October, and produced 24 chapters over the next 20 months until the beginning of June, 1937. Zhang himself recalled, “...the subject was the background of the models. I wrote about an old style girl, who becomes a model in a school because her family is poor. It was in every way a tragedy, and I was confident it would be different from the way other people wrote about models." 69 ……我并自写了一篇小说, 叫《艺术之宫》, 这个题材, 是以模特 为背景的。写一个守旧的女子, 为家穷而去学校当模特。完全是以一个悲剧姿态出现 的, 自信和他人写模特不同。

The Art Palace is perhaps one of the most closely observed depictions of the modern Chinese art world we have from this period. As a consideration of creative space and the problematic and politics of representation confronting artists in their own time and place, it can be read alongside other writing on the topic, most notably Zola's The Masterpiece (L'Oeuvre, 1886 ) or Balzac's "The Unknown Masterpiece" ("Le chef d'oeuvre inconnu", 1837).

Zhang's depiction of the structure and inner politics of a Beijing art school was fiction but extremely well researched, most likely based on his own experience. It is clear from his memoirs and his son's reminiscences that Zhang's own preference was for classical painting and his interests lay in artistic innovation that found its sources within the Chinese tradition itself. In the novel, however "art" is an emphatically Western construction. In the hallways of the school, aside from the occasional professor in a long gown, and the distinction between western and "national style painting" on the course schedule in the administrator's office, traditional art stays firmly behind the closed doors of the school corridors.

The plot of the novel is fairly straightforward. The heroine, Xiu'er 秀儿 keeps house for her father in a small room off a common courtyard with her widowed father Li Sansheng 李三胜. Li earns his living by maiyi 卖艺 (literally, "selling art"), performing as a street entertainer. In the opening scene, the sixty year-old father misses a step and collapses, exhausted by his exertions. He is bedridden and

${ }^{68}$ Zhang Wu, p. 173.

${ }^{69}$ Cited by Zhu Hongling in an article on «Yishu zhi gong», appearing in Yang Yi, ed., Zhang Henshui mingzuo xinshang. Beijing: Zhongguo heping chubanshe, 1996. p. 225. 
soon the family is destitute, with no way to pay for rent, coal, food, or water.

As Xiu'er faces the daily humiliations of dire poverty, she notices that new neighbors have moved in across the street. The Wang sisters and their friends $\mathrm{Xu}$ Xiuwen 徐秀文 and $\mathrm{Ni}$ Changzhen 倪长贞 seem to have business outside the home. They are beautifully dressed and well fed, they live in clean and well appointed rooms. The other neighbors are suspicious, but slowly the girls make friends with Xiu'er, first offering tea and dumplings, later lending money. Finally the girls reveal the source of their income: they are models in an art school. Xiu'er is shocked, but fascinated. As her new friends explain it, the work is simple-she has simply to sit still and let students look at her. The payment--30-40 yuan a month-seems astronomical. Xiu'er is a modest girl, and looks at the question from every possible angle. In a novel of 24 chapters, she does not get to the gates of the Arts Institute until chapter 10.

Xiu'er is pretty and is soon in demand within the school. She is pursued relentlessly by one of the leading students, Duan Tiande 段天得. One of the instructors, a Professor Jiang 姜, recently returned from France, is also fascinated and asks that she works supplemental hours at the Arts Palace, a private atelier he has set up for fellow artists. Xiu'er has told her father that she works as a servant in the school. He is not happy, having raised his daughter to be a good girl (zuo guniang 做姑娘), to let her work, but sees he has no choice. A close friend of the family, Wan Ziming 万 子明, approaches the family with an offer of marriage. Xiu'er wavers, it is a clear choice between money and love, and she is not sure which one is more important to her. But the decision is moot when Li finds out what his daughter has really been doing, and he swears to kill her. Xiu'er is dissuaded from going home and moves in with Duan. Li packs up and leaves the courtyard, determined to go back to street art, this time in Tianjin. His health is not completely recovered, the performances are grueling, he dies of exhaustion. Xiu'er, who knows nothing of her father's death, discovers that Duan is already married. She decides to return home, determined to face her father. It is only when she arrives at the hutong 胡同 gate that she is told the news of his passing. The art school, meanwhile, is engulfed in scandal, stemming not from the models, but from the abuse of funds used for the still life class displays. The Ministry of Education intervenes, the administration is replaced, certain troublesome students, including Duan, are expelled, and Xiu'er, who has been groundlessly compromised in a sex scandal, is no longer welcome at the Institute. Instead, she is asked to work full time at the Arts Palace where the atmosphere in the atelier has become progressively more dissolute. In the final scene, Xiu'er is wandering around in the half light of midnight, unable to find her 
way out of a winding hutong, her mind disintegrating into madness.

The themes running through The Art Palace are part of Zhang's standard repertoire. Innocence, often female, always young, is irredeemably lost. The heroine has no choice in the matter, but she is not perfect, and is usually complicit either through ignorance, stubbornness, cowardice, or greed, in her own downfall. There is the camaraderie of hutong life, the decency of some poor families, the way those who have little extend whatever help they can to those worse off than themselves, but also never hesitate to criticize or gossip about the same. There is the selfishness and just barely imaginable luxury of the very rich. And there is of course the confrontation between traditional rural values and urban modernity.

The ateliers in The Art Palace, however, are something different, and so is the tension they generate in the narrative. The atelier and the art institute are seen for the first time through Xiu'er's eyes on the day of her audition:

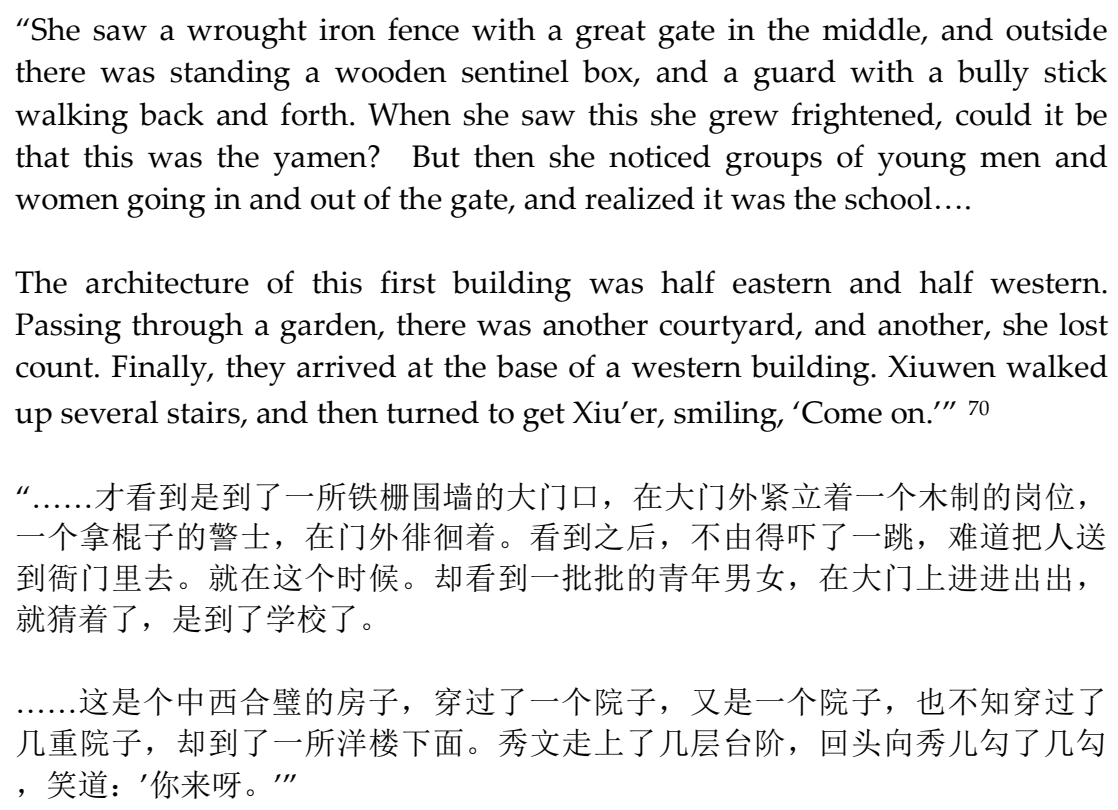

"She saw a wrought iron fence with a great gate in the middle, and outside there was standing a wooden sentinel box, and a guard with a bully stick walking back and forth. When she saw this she grew frightened, could it be that this was the yamen? But then she noticed groups of young men and women going in and out of the gate, and realized it was the school....

The architecture of this first building was half eastern and half western. Passing through a garden, there was another courtyard, and another, she lost count. Finally, they arrived at the base of a western building. Xiuwen walked up several stairs, and then turned to get Xiu'er, smiling, 'Come on.'” 70

“...... 才看到是到了一所铁棚围墙的大门口, 在大门外紧立着一个木制的岗位, 一个拿棍子的警士, 在门外俳徊着。看到之后, 不由得吓了一跳, 难道把人送 到衙门里去。就在这个时候。却看到一批批的青年男女, 在大门上进进出出, 就猜着了, 是到了学校了。

……这是个中西合璧的房子, 穿过了一个院子, 又是一个院子, 也不知穿过了 几重院子, 却到了一所洋楼下面。秀文走上了几层台阶, 回头向秀儿勾了几勾 , 笑道: '你来呀。”

Xiu'er is led into the administration office where she meets the administrative dean. Her salary is discussed and she learns that she has to meet the approval of first this dean, then the dean of the arts, and finally the painting professor. Following her friend quickly through corridors and staircases, she finally catches her first glimpse

70Zhang Henshui, Yishuzhigong, Beijing:Beijing yanshan chubanshe, 1992, p. 115. 
of the atelier.

"It was a building about 50 feet across, and walking into the main hall they saw seven or eight male students; all of them stared. Xiu'er, who had never been looked at like that before, began to blush, and ducked her head. The good thing was that although these students were staring at a female, their own faces were completely expressionless, without a single smile. Xiu'er thought, if they are going to be like this, and look at me so respectfully, it will be fine. She began to feel calmer...."71

“这里是一所五开间的大屋子, 进了天中的堂屋, 顶头遇见七八人男学生, 全把 眼睛向人身上钉了来。秀儿那里经过人这样看过, 不由得飞红了脸, 把头低了 下去, 所幸这些学生, 虽是把眼睛向妇人看着, 可是他的脸色, 全是板得铁冷 的, 一丝笑容没有。秀儿这就想着, 若是像他们这样, 规规矩矩的见着面, 那 倒没有什么要紧。”

Xiu'er is put to work later that afternoon. She still thinks that she will be required only to sit and pose for the students. She is taken to No. 5 classroom. She finds the atelier filled with easels placed every which way, each with its own palette and mounted with white paper.

"The red paintings were of apples, the green of bananas, the grey of bottles and tins. The white and yellow paintings were of human heads or busts. On the wall were tacked several drawings, all of them nude women, both of the Wang sisters, Ni Suzhen and Xu Xiuwen, everything was there, the women's breasts were painted very vividly. This was really something, could it be that in a place were books were studied, there were such carrying-ons? Wasn't the teacher paying attention?"72

“......红的画着苹果, 绿的画着香蕉, 灰黑色的画着瓶子罐子。白的和黄的, 画 着人脑袋和半截身子。这都罢了，墙上钉有几张画，全画的是光眼子女人，王 家姐儿俩, 倪素贞、徐秀文的像, 全画的有, 姑娘家那两个大乳, 画得活灵活 现。这可是新稀罕儿, 念书的地方, 有这么闹着玩的吗? 这个样子, 难道先生 全不管吗?"

She notices that all the windows are carefully covered with white paper, and a big cupboard which was like a kang, with a bedspread on top. In the corner was a four panel screen which seemed to be hiding something. Next to the screen were two low tables covered with fabric and set with items for a still life, including spinach and turnips, a basket of apples, and a dead duck.

Class begins. Twenty to thirty students file in and take their places at their easels.

${ }^{71}$ Zhang Henshui, p.118.

${ }^{72}$ Zhang Henshui, p.122. 
They look Xiu'er over, and she thinks they will start painting soon. The professor arrives and shuts the door carefully. When he sees Xiu'er he asks, "Why haven't you undressed yet?"73 He tells her to get behind the screen and undress quickly, people are waiting. When the students snicker, the teacher turns on them, "It's her first time and she doesn't know the protocol." To Xiu'er he advises her, "Go and strip. It's nothing, it's for Art, so one can be a little more liberal."

"Xiu'er had already heard this word "Art" at the Wang's, and it already seemed quite familiar to her. Although she didn't know the characters, or what it actually meant, the minute it was mentioned, it seemed hugely important. Even words like loyalty, filiality, humanity and righteousness (zhong xiao ren yi) didn't have the same perfume. Xiu'er thought, if it was about Art, then she would take her clothes off for that." 74

“你去脱衣服罢。这没有什么, 为了艺术, 可以大方一些。”秀儿在王氏姊妹家 里, 艺术两个字, 听也听得烂熟了。虽不知道艺术两个字, 当什么意思讲, 可 是一抬出来, 却很重大的, 似乎忠孝仁义, 全没有这两个字吃香。秀儿想既然 说到艺术，那就为了艺术去脱衣服罢。”

The professor shows her behind the screen. Xiu'er can see everyone is waiting quietly and moreover she has already accepted payment. She takes off her outer garments, leaving a pair of short trousers:

“Mr. Chen said, 'Hey! What are you doing? Please hurry up.' As he spoke his hand grasped the screen, and he looked over the top. 'Hurry up and strip, I'll lose my patience otherwise.' Xiu' er heard the tension in his voice and had to take off the shorts as well. Underneath there was still a red vest fastened tightly down the front with white bone buttons, binding her bulging breasts. She looked down, her bare arms felt an unaccustomed chill. Because the people outside the screen were in a hurry, she couldn't dawdle any longer. She steeled herself, she lowered her head and walked out from behind the screen, but as soon as she did, the entire room burst into laughter. Frightened, her arms wrapped around herself, she bolted back behind the screen. Mr. Chen shouted, 'Are you going to do it or not?' Xiu'er replied in a low voice, 'Of course I am, but why are they laughing at me?' Mr. Chen answered, 'Who told you to keep your under things on. Listen, your underpants have to come right off, socks and shoes as well. If you're not going to do it, then you shouldn't have come. Now that you're here, and hesitating like this, taking one step forward, two steps back. Have you got anyone else at home? We'll have to send someone over there and ask them to pay compensation, it's really

${ }^{73}$ Zhang Henshui, p.122.

${ }^{74}$ Zhang Henshui, p.123. 
perverse, sending someone like this to us!'” 75

“陈先生道: ’喂! 你怎么啦? 快点儿罢。'他说着这话, 手扶了屏风, 向屏风头 上, 伸出脑袋来张望。轻喝了一声道: '快脱了出来, 不脱, 我可急了。'秀儿听 到他那种发急的声音, 只得把那件短补子也脱了。里面还有一件紧身红布小背 心呢, 胸面前紧紧的一排白骨扣子, 把两个乳峰，束得包包鼓鼓的。自己低头 一看, 光了两个手膀子, 也透着怪寒碜的。只是人家外面催得很急, 这可就不 能耽误了, 一横心, 就低了头走出来。不想刚出屏风, 全堂一阵哈哈大秀。吓 得自己抱了两去手臂, 回转头就向屏风里一钻。陈先生大声喝道: '你到底干不 干? '秀儿低声道: '我怎么不干啦, 可是他们全笑我呢? '陈先生道: '谁还教你 上下衣服全穿着。我告诉你, 连裤子也得解下才算, 袜子鞋子也脱了。你不干 , 你就不该来。你来了, 你又这样推三阻四的。你家里还有什么人? 我们得派 人到你家去, 要你们赔偿损失, 弄这么一个人来, 真獘扭! '”'

Xiu'er is terrified her father will find out. She reproaches herself bitterly for wanting to earn the thirty yuan per month for the job. Now that she is here, she sees no other choice.

"She was a bit crazed, and also angry, and undid the buttons on her vest, pop pop pop, tearing it off in one gesture, throwing it onto the stool, and then stripping off the rest of her underwear. Mr. Chen was walking back and forth on the other side of the screen, looking over to check that she was doing it. When he saw that she was almost ready, he hissed, 'Hurry up! We've waited too long.' Xiu'er sat on the stool and took off her shoes and socks. Everything was off now, but she was sitting facing the wall, not daring to face the screen. She realized that near the screen were two small stoves heating up the room. It was still early autumn, and normally there was no need for this kind of heating. Now she understood; it was for the models who stripped. She was naked, and she wasn't sure if it was because her nerves were so overwrought that her body was heating up, or because of the stoves, but even without a stitch of clothing, she felt warmer than she did fully dressed. She finished taking off her shoes. She was still deciding, should she go out from behind the screen or not?"76

“她也莫明其妙的, 有些生气了, 把胸面前这一排纽扣, 卜碌卜碌, 一阵风似的 解开, 脱下背心, 提起来向方登上一抛, 接着把别的下衣也都脱了。陈先生只 管在风外面徘徊, 用眼睛不断的向里面射了来了, 也就看到她, 已经是把衣服 全脱完了的了, 这就向她轻声喝道: '快些! 等你太久了。'秀儿这才坐在那方登 子上，把袜子鞋子，全都脱下来，可是背转了身子朝墙里，不敢对着屏风。同 时, 自己才明白过来, 靠着屏风不远, 还烧着两个白炉子, 屋子里兀自热哄哄 的。像这样的初秋天气，本来是用不着这个，倒有些疑惑，原来是为着模特儿 脱光了衣服用的。现在把衣服脱了, 不知道是心里发慌, 闹得全身发热呢? 也

${ }^{75}$ Zhang Henshui, pp.123-124.

${ }^{76}$ Zhang Henshui, pp.124-125. 
不知道是靠近了炉子, 身上烤得发热呢? 总之, 自己脱得根纱不挂, 比穿了衣 服, 还要热些。自己正如此想着, 慢慢的把鞋子全脱下来。心里还在那里打着 主意, 还是出去呢不出去呢?"

Xiu'er berates herself for being poor, for being in need. She equates her predicament with torture or execution. People who are rich have no need to sin, she thinks. She is still trying to figure out how to leave.

"Suddenly, Mr. Chen moved the screen brusquely away, folded it up and propped it against the wall. Xiu'er was immediately exposed, her back to the students. She turned to look, frightened, she crouched over, her hands covering her lower torso. Her heart felt as though it were on a swing, as if were about to jump up into her mouth. Her thighs began to tremble.

She was aware of being naked, but forgot where she was, it was as if she had already died. Mr. Chen said, "Hey, you can turn around now, it won't do to sit back here, you have to sit on the kang." It wasn't clear whether Xiu'er hadn't heard him, or was too afraid to turn, she just sat there, not moving. Mr. Chen could no longer be polite, he grabbed her by the arm and dragged her over to the kang. Xiu'er didn't dare to lift her head, and staggered over. In the middle of her panic, she glanced at the students and saw that every single one was staring at her, but without any kind of frivolity, as if a naked woman standing in front of them were no more than a clay statue, a very normal thing. She had no idea how she had come to be sitting on the kang, and didn't know when Mr. Cheng let go of her and stood back, arms akimbo, looking her over. He seemed to know that Xiu'er had lost her bearings and said to her, 'turn your body a bit that way, right hand holding the right side of your face, left hand up, holding the back of your head.' At first Xiu'er didn't know what he was saying, but he repeated it several times, and finally she understood and did as he asked. Mr. Chen said, 'Good! Just sit like that, don't move, your face should be more natural, you don't have to look so frightened. Hey! are you going to tremble at anything I say?' It was only when he said this that Xiu'er realized she was shaking."77

“不想那些位陈先生, 却来个绝着, 两手抱了屏风, 突然的向旁边一推, 叠着靠 墙放了, 立刻秀儿成着光了身子, 背对着人坐了。她回头一看, 吓得两手按了 小腹, 把身子弯了下去。一颗心像打秋千一样, 直要跳到口里来。同时, 两只 大腿，只管打哆嗦。

她不但知道是脱光了衣服, 而且也忘了是坐在什么地方, 人坐着死过去了。陈 先生道: '喂! 你现在可以掉转来了。坐在那里不成, 你得坐在这木炕上来。'秀 儿不知道是没有听到, 也不知道是听到了不敢回转身来, 依然那样坐着, 动也 不一动。陈先生不能和她客气了, 手里抓了秀儿一只胳膊, 就向这木炕边拖过

77Zhang Henshui, p.125-126. 
来。秀儿被他拉着回转身来, 也不敢抬头, 跌跌撞撞的, 走了过来。在这样百 忙中, 也曾偷眼去看看那些学生, 见他们全是䜻了两眼望着, 并不带什么轻薄 样子, 好像是一个光眼子姑娘站在他们面前, 也不过是在这里摆着一个大的泥 人儿, 事情是很平平常常。不知道自己是怎样的坐到这木炕上来了, 也不知道 陈先生是什么时候放下了手, 他两手叉了腰, 站在旁边, 向秀儿望着。他似乎 知道秀儿失了知觉, 于是向秀儿道: '把身子歪一点坐着, 右手撑往右脸, 左手 抬起来, 扶着后脑勺。'秀儿先是不知道这些话, 经陈先生接二连三的, 说过几 句之后, 她才明白了, 就照着他的话, 作了那个姿势。陈先生道: '好! 就是这 样坐着, 不要动, 脸上可以自然一点子, 不必做出那害怕的样子。咦! 怎么只 劝你, 你只发抖? '秀儿被他一句提醒, 才知道身上在哆嗦。”

The description of Xiu'er's first modeling session is tortuous, and reads like a textual rape. Her undressing is a slow striptease, not only for the students, but for the readers. The exclamation points beat out the rhythms of Xiu'er dilemma and the teacher's mounting exasperation as he forces her to strip, the dispassionate gaze of the students functions almost like a Greek chorus to the action in the atelier but also to the action of reading the text. In stripping the model, Zhang has also come close to stripping away representation itself, and the reader become complicit in Xiu'er's exposure. And all, it would seem, for Art.

In another painting class, the professor, a Mr. Yu, is lately returned from France and has advanced ideas about art.

"He had also had a theory, which was that this thing called Art came out of the self and could teach others, and one could thereby influence them. Thus, works of Art had to be exaggerated and stimulating; to paint the human body, according to this theory, was no different. Therefore he did not advocate that models sit, as it was too boring, and wasn't stimulating. He asked Xiu'er to hold a clean soccer ball, to balance it on her right shoulder, and to put her legs close together. With the ball on her right shoulder he then asked her to raise her left hand behind the neck to hold the ball from the other side. Up to now, in whatever pose she had taken, Xiu'er had had some way of shielding part of herself, but with today's pose, her entire front was exposed, which was somewhat more embarrassing.....she told herself, I am dead! Let them look at what they want to." 78

“而且他对艺术, 还有个原则, 就是艺术这样东西, 必须自我出发, 能够教别人 , 受我的影响。唯其如此, 所以艺术作品需要夸大, 要刺激, 画人体, 对这个 原则, 也不能例外。因之他不主张模特儿坐着, 以为太平庸了, 不能怎样的刺 激人, 却教秀儿手捧了一只干净的足球, 放在右肩上, 让她并拢两脚, 挺立的 站着。右手扶着肩上的球, 左手却是由脖子后面绕了过来把球托住。秀儿在以 往的几堂课, 或是坐着, 或是睡倒, 对于自己的肉体, 多少有些掩蔽之处, 像

78Zhang Henshui, p.151-152. 
今天这样的完全暴露, 还是整个儿正面孔看人, 倒是有点难为情。心一横, 把 两只眼睛, 呆呆的朝前望着, 就像什么全没有放到眼里一样, 课堂上虽是有那 些个学生, 只当是一间小小的空屋子。心里还在暗暗的告诉自己, 我是死人! 他们爱怎么照就怎么照。”

The professor steps back, pleased with his work. While his students paint, he lectures them:

“No matter what we are painting, we must paint the lively, not the stiff and still. Put another way, aside from painting the form of beauty, we must paint the beauty within the form. For example, if we painted a lion, and drew in every hair, it would be very accurate, but not skillful. We must depict the lion's hunger, the lion's urgency, even the lion's desire to eat men. In painting humans we must take this even further. We must paint his soul, we must look for the wherewithal of his life. Flesh has nothing to do with it. Just think, to paint someone's likeness, anyone with a camera can do it, right? We use the gaze of Art to see everything in the universe....Ai! What happened?"79

“我们无论画什么东西, 要画得灵活, 不要画得呆板, 换句话说, 就是画出 形态以外的美, 还要画出形态以内的美。比如画一只狮子吧, 你把狮子每一根 毛都画了出来, 就算画得像极了, 那也不算本领, 我们必得把狮子饿了, 或者 狮子急了, 甚至于狮子要想吃人, 把那意境描写出来。画人自然要比这还要进 一步。我们要画出他的灵魂, 要寻找出他的生命之所在。肉体, 那是无关的。 你想, 只画得一个像的话, 用照相机, 大家各照一张相, 那不是每个人所得的 ，都很对吗？我们用艺术的眼光来看宇宙内的一切，......咦！怎么了？......"

Duan Tiande, has fainted at the sight of Xiu'er, his spilled paints lying everywhere around him.

The lecture of Professor Yu exemplifies the thinking about Art (yishu 艺术) in the atelier. It is a new Western religion, dependent on "inspiration" (yin shi pi li jun in the text--a borrowed English word rather than the Chinese linggan 灵感), but also dependent on the real. Models are "sacrifices" on the altar of art, and as such, treated with respect and objectivity in the atelier. Art is representation, to which the atelier is consecrated as "disciples" gather together at their easels to practice its rituals with an assiduous and solemn asceticism, untouched by base desires. The recourse to realism sounds familiar-it is the echo, or the debasement, of the call that Chen Duxiu and Lu Cheng made sixteen years earlier in the pages of New Youth.

Because she is pretty, Xiu'er is soon in great demand. A group of second-year

${ }^{79}$ Zhang Henshui, p.151-152. 
students, led by Duan Tiande and his friend Zhang Zhengming, ask to have extra sessions with her. The dean refuses, saying they aren't ready for it, but as a consolation they can paint anything they like in their still-life class. The students march off to the bursar and hand in a list of items: Three stewed ducks, several strands of American sausages, four loaves of bread, and two bottles of three-star brandy. After their painting session, they will have a mouth-watering feast, all at the dean's expense. The bemused bursar obtains most of the menu, even going across town for the foreign sausages, but he thinks the brandy is too expensive, and suggests that the students simply paint bottles filled with colored water. Duan Tiande will have none of it:

“'What do you mean it doesn't matter, do you know how to paint?' Bursar Ma laughed, 'What do I know about painting? If I could paint, I wouldn't be doing what I do now.' Zhang Zhengming interrupted, 'Well doesn't that settle it? If you don't paint, what are you talking about! Art has its own reality, if one wants to paint brandy, one must really paint brandy; an empty bottle won't suffice. If an empty bottle would do, when we paint fruit, we would just paint wax ones, why paint real fruit...."'80

“......'没关系, 你知道画吗? '马庶务笑道: '我那里会画? 我会画, 不干现在这 个职务啦。'章正明道: '这不结了? 你不会画, 你多说什么! 艺术有它的真实性 , 要画白兰地酒, 就得真正的画白兰地酒, 用空瓶子, 是不能替代的。若是空 瓶子能替代, 我们画起水果来, 用蜡做的模型替代就得了, 何必画真水果。 ...'”

The students bully the bursar and the dean of arts into purchasing the brandy. Meanwhile, the class begins. Professor $\mathrm{Wu}$, a genial man in a long robe daubed with paint, directs the students to paint the table loaded down with food. Suddenly $\mathrm{Ma}$ arrives with the brandy. The classroom breaks into pandemonium. $\mathrm{Wu}$, who knows nothing of the previous discussion, is only thinking of how he can take the bottles for himself. The students swarm toward the table, and begin to fight over the duck and the sausages, everyone grabbing for themselves. Only the women students stand aside, watching in stunned silence. Duan Tiande calms the crowd down by reminding them that the food had been ordered as a maneuver to get more life-drawing class time, not to get a meal. Professor $\mathrm{Wu}$ is standing by the window, holding the two bottles of brandy and an entire stewed duck. One of the students is suddenly moved to take his photo. He walks out of the classroom, intending to take the liquor with him, but the students stop him and take it back. Affronted, he marches out, declaring that nothing can be done with such students. $\mathrm{Ma}$, who has been standing by the door and seen everything, follows him out,

${ }^{80}$ Zhang Henshui, p.142. 
asking, "Mr. Wu, you're a teacher, and you know ten times as much as the students. Is it true that in order to paint wine bottles, you must have bottles with real wine?" “Who says so," mutters Wu. ${ }^{81}$ “先生, 您是当先生的人, 总比学生高明 十倍, 画酒瓶子一定还得瓶子里有酒吗? ”伍教授道: “那有这话? ”

It is not only the students who want to see more of Xiu'er. One of the instructors Mr. Jiang arranges that she work extra hours at a private arts club he has set up with some friends, the "Art Palace." The club is set up in a traditional siheyuan house with a courtyard set with four huai pagoda trees and two stone camels. There are no servants and the club members serve themselves. The rooms are sparsely furnished with traditional chairs and desks. At first Xiu'er feels safe, thinking the elegance of the setting connotes serious behavior, but instead of beginning to paint immediately, the men want to talk first, and she becomes more and more uncomfortable. She agrees to model, but only for one hour. When she mounts the platform the men begin painting.

"In the room there was no clock, nor was there anything like the Institute's classroom bell. Xiu'er sat quietly on the wooden kang, waiting as the four men drew. She was thinking, hasn't it been an hour yet? As she thought, her brow began to wrinkle, Jiang was looking at her and then painting, back and forth very quickly, when suddenly his brush stopped and he said, 'What is it, Miss $\mathrm{Li}$, are you worried about something?' People who are models also have a lot of secrets, but as soon as they've taken off their clothes, while people are looking at them, they have to turn themselves into soulless wooden statue, the eyes not seeing anything, the ears hearing nothing, and naturally they don't speak either. But when Jiang asked, she had to answer, and said, 'It's nothing.' Jiang shook his head, 'No! I can see it in your face, you're very worried about something.'"'82

“......这屋子里并没有挂钟, 又不像学校里有下堂钟报告。秀儿只有静静的坐在 那森炕上, 等这里四位先生去描摸。心里这就在那里想着, 怎么还没有到钟点 ? 心里老是如此想着, 眉毛可就只管微微皱了起来, 姜先生对着她身上看一笔 画一笔的, 正是得劲, 忽然将笔停住, 对秀儿脸上看了一看, 嘴里吸了一口气 ，作出一个踌躇的样子来，问道：'怎么回事，密斯李，你惦记着什么事情吗？' 作模特的人, 也有许多神秘, 当她脱光了衣服, 尽人赏鉴的时候, 她总是把自 己当了一个失去灵魂的木偶, 眼睛不瞧到什么, 耳朵不听到什么, 自然也不张 嘴同人说什么。这时姜先生当面问她的话, 不容她不答复, 便低了头道: '不想 什么。'姜先生摇摇头道: '不! 我在你脸上看得出来的, 你很发着愁呢。'

One of them looks his watch and discovers they have been painting for more than

${ }^{81}$ Zhang Henshui, p.146.

82Zhang Henshui, pp.201-203. 
two hours. Abashed, they let her go. She has been immobilized by their gaze, held hostage to time. By now, it is not just the nudity that is the problem, it is the control they exert over her, down to the expression on her face.

In the novel, these two alternate ateliers - the still-life room and the Art Palacedemonstrate the displacements that are the logical conclusions of Art. The connivance of the students to buy their meal, their recourse to speaking of high artistic principals in order to get their way, and the pure greed that overtakes them as they attack the tableau of food, all foreshadow the actions of the art students and professors in their relations with the model Xiu'er. Although they are trained to gaze formally at an object in order to make its image, they ultimately consume their objects without ever, it must be said, creating anything. Aside from the throwaway sketches painted in the past, we never actually see any of the painting that is supposed to be the prime purpose of these artists' lives. The uproar over the food and liquor could just as easily be mass debauchery in the life drawing class-there are social limits, after all, both in the classroom, and off the page in publishing offices.

The still life class thus exists in the novel as a kind of reproach. Why not paint wax fruit instead of real fruit, Zhang is asking, why not paint statues instead of real people. Why do real human beings have to be sacrificed as objects for Art? The protestations the students make over the "realism" of the brandy are shown to be hollow and self-serving. When Xiu'er has a breakdown on stage after she realizes her neighbors have found out what she does for a living, the women students are directed to help her back into her clothes. "Don't worry," they say, trying to comfort her, "take some time off, we can paint the plaster models." 83 It is the only time they speak.

At the arts club, the tension between ideal and desire is played out differently, this time reflected in the ambitions of Professor Jiang. In the school, once the image of Xiu'er has caused Duan to faint, she is attributed with a power that fascinates the entire school. Jiang is convinced that if he can translate it into paint, he will have a masterpiece. Although he flirts with her, he is not really interested in possessing her physically. What he wants is to use her as a medium.

"We want to paint our feelings of joy, anger, grief and delight, and for that we need human subjects. If we can use objective ways of getting subject matter, and then use subjective judgment to construct the painting, it becomes a good

${ }^{83}$ Zhang Henshui, p.310. 
work. Anyone who can use a brush can paint a body. If we paint, it is only if we paint the model's soul that we can put our emotions in the right place, and then let our art influence people. If we want our art to succeed, we must use this method, we must work hard from this angle." ${ }^{\prime 84}$

“......要把我们喜怒哀乐的情感画出来, 那还是以人为题材好。我们能够用客观 的手腕去找题材, 而后以主观的判断, 构成画面, 这就能成为好的作品。画人 的躯壳, 会动笔的人, 那是尽人能为之的。若是我们画, 必定要画出模特的灵 魂来, 那才让我们的情感, 有所寄托。同时, 才能叫我们的艺术, 可以影响到 别人。我们要艺术成功, 必得有这样一种手腕, 我们要从这一方面去努力。”

When he realizes he will have to go back to the school to finish his portrait of her, he rolls it up the canvas "and in a strange gesture, [brings] the roll up to his nose and took a deep sniff." 85 To get more modeling time with Xiu'er, he shows the painting to Dean Liu:

“Look, this is a painting I have meticulously constructed (jingxin jiegou 精心结 结构). I've been looking a long time for a woman with this kind of face, the problem was there was no one with a soul. For the last couple of years, I've worked with so many models, none of them were right. Now, finding her, I'm ecstatic. She's let me paint only a part of her and won't let me finish, it's very disappointing for me."

“你看, 这是我精心结构的一张画。我早就要找一位这样面孔的女人, 题目是没 有灵魂的人。有两三年了, 也不知道遇到多少模特, 全不合适, 好容易, 遇着 她了, 我欢喜得什么似的。她偏是让我画了一大半, 不让我画完, 这样教我非 常的失望。”

Liu can't resist holding up the painting to take a good look at it. Jiang stands next to him, chomping on a cigar, “You see! It's great, isn't it?" “你看这不是画得很好吗?"86

The club's atelier is a deceptive space, constructed of pure traditional elements, reminiscent of the traditional male studio, the zhai, where men met to amuse themselves and communicate over wine, poetry, music and women. Consequently, there is also an element of leisurely voyeurism at the Art Palace. Men arrive, planning not to paint but to watch other men paint, to witness the chemistry of the exchange between model and artist. Without really understanding why, it is this that Xiu'er takes most exception to. Beneath the double gaze, she is doubly stripped, doubly bereft.

${ }^{84}$ Zhang Henshui, p.207.

${ }^{85}$ Zhang Henshui, p.210.

${ }^{86}$ Zhang Henshui, p.213. 
In the private studio, Zhang Henshui brings together the imported modernity of Western representation and the louche urbanity of late-Qing courtesan culture. ${ }^{87}$ He shows foreign-trained intellectuals deploying old style forms of coercion and exploitation. But the reasons for this manipulation are new. They lie at the crux of this new imported version of representation. Professor $\mathrm{Yu}$ in the school atelier insists that Art requires that one paint the rage of the lion, his hunger and his taste for the flesh of man. Professor Jiang insists on gaining more access to Xiu' er because only with her as his model can he paint the painting he has wanted to do for years. He is the only one of the characters to mention the artist's own emotions, but insists that the model is intrinsic to the expression of them. Yet his practice of these theories is dubious. His colleagues tip their heads and look at his half-finished masterpiece every which way. Despite themselves, they cannot see what he is talking about.

In The Art Palace, the focus of mimetic representation has moved away from the painter, away from the process of translating object into surface, and even away from the finished work of art. Instead, the focus is on the object: the model, the bottles of wine, the stewed duck or the dead one. Zhang Henshui is showing the dark side of what happens when intellectuals succumb to what CT Hsia has classically formulated as "an obsession with China." 88 For the artists, their obsession with representation is about self-representation as well. The use of the model is a kind of deflection, the kind of slippage that blinds the artist to what is in front of him, pushes him to project his own desires on passive ground, to indulge in wrong proportions and lascivious emotions, and to pursue useless illusions. $\mathrm{He}$ takes too much power, using the tools of Western representation to produce art that will represent China. The woman in the picture is no longer a gendered being, but a national object. The model is colonized, reduced to victim, but both sides will be destroyed by this imbalance..$^{89}$

In contrast, traditional Chinese street entertainers, the men and women, like Xiu'er's father, who maiyi-sell their art-give their lives to their work. Li Sansheng enacts his art for almost no recompense, and dies of exhaustion and chagrin. For Zhang Henshui, who is concerned with the conflict between tradition and the West,

\footnotetext{
${ }^{87}$ In the sense, the Art Palace club can be seen as a reflection on the context of Zhang's own writing. Although Libao, the paper that serialized his novel, is a new type of periodical, the serialized form of his story is left-over from the late Qing dynasty, and in generic terms this means that Zhang's work has always been grouped firmly with old-style, mass entertainment.

${ }^{88}$ C.T. Hsia, A History of Modern Chinese Fiction, second edition, New Haven: Yale University Press, 1971, p.536. ${ }^{89}$ The formulation is taken from Albert Memmi, The Colonizer and the Colonized (1957), trans., Greenfield, Howard. London: Earthscan Publications, 1965, p. 219.
} 
and the unequal evaluation of high and low art, this is the crux of the matter. One can simply place Art on a pedestal and paint it, or one can enact art with one's own body. He is unequivocal about which strategy he prefers.

For Zhang Henshui, the purpose of representation is ultimately a moral one and must be conducted in a moral way. It is the only way he can reconcile such suspicious activities. His own storytelling also ultimately aims at "painting reality", and "capturing the soul". His character portraits ring true, even if sometimes his plot devices do not. But he does something that in representational terms is extraordinarily modern: he lets his characters go.

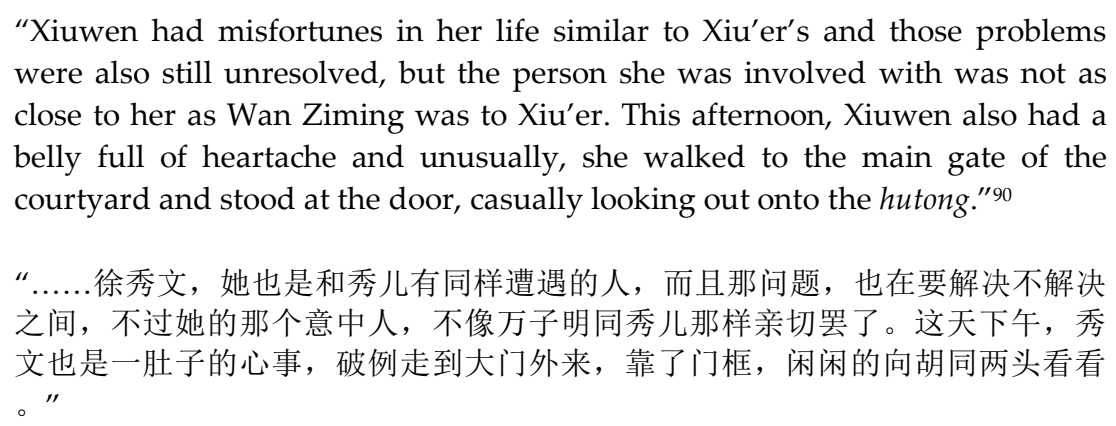
were also still unresolved, but the person she was involved with was not as close to her as Wan Ziming was to Xiu'er. This afternoon, Xiuwen also had a belly full of heartache and unusually, she walked to the main gate of the courtyard and stood at the door, casually looking out onto the hutong."90

“......徐秀文, 她也是和秀儿有同样遭遇的人, 而且那问题, 也在要解决不解决 之间，不过她的那个意中人，不像万子明同秀儿那样亲切罢了。这天下午，秀 文也是一肚子的心事, 破例走到大门外来, 靠了门框, 闲闲的向胡同两头看看 。”

It is near the end of the novel, and it is the first time we hear about Xiuwen's love life. We never meet her suitor, and we never know what happens. These loose ends are deliberate. It is important to know that things happen off the page, outside of his story. He takes the characters' stories, but does not seek to possess them entirely. It is an acknowledgment that art and representation are incomplete entities, and only one way of looking at things. As a writer, Zhang is a painter too. He shows us pain and humiliation, but he also shows us blank space. It is a space that is exhortatory, even celebratory, of what the human condition is.

In the end, perhaps the art in The Art Palace finds its proper place, not in the atelier, but in the small rooms the models have made for themselves. The spaces are clean and neat, the walls freshly whitewashed and the windows fitted with smooth unbroken paper. There is even a “fake sofa" (jia shafa 假沙发) made with bricks and planks of wood. Xiuwen is still standing in her doorway:

"In the golden light of the sunset, the hutong splashed with water, suddenly two or three birds flew over, rising above her head straight up into the air. This seemed to amplify her feelings. Xiuwen had worked for over a year as a

${ }^{90}$ Zhang Henshui, Yishuzhigong, p.290. 
model. When it came to what had artistic flavor, of course she had deeper feelings than the average person. She looked up to see the wall across the way, hung with thin branches still left with a few sparse leaves. Along with the clear color of the sky and the red of the clouds, it was very beautiful. A big flock of chickens and ducks flew onto the thin branches and perched there, as if the branches were covered in round black fruit. Although Xiuwen had troubles in her heart, she felt happy looking at this scene."91

“那金黄色的霞光, 酒满了一胡同, 偶然两三支飞鸟, 由人头上飞过, 那也倍觉 有情。秀文在艺术学校里作了一年多的模特儿, 对于什么是有美术意味的, 当 然比平常的人感受得要更深切些。昂了头看对面人家一道围墙, 拥出一从落叶 萧疏的树梢, 配着青色的天, 红色的云, 很是好看。一大群乌鸦, 飞到树梢子 上站着，仿佛在那树上，结了很多黑色的果子。秀文虽是心里颇有点烦恼的人 , 但是在这种情形之下, 精神也觉得很是舒畅。”

Unlike the traditional and May Fourth intellectuals who worried about the dangers of exposing the masses indiscriminately to pictorial images, Zhang Henshui sees hope in the eyes of a young woman. Unlike the corrupt art students and teachers, Xiuwen is able to recognize and draw direct comfort from the beauty she finds in everyday life. The producers of art are lost in a morass of cultural and sexual confusion, but inadvertently it is the model who has learned to look, to become, in some way, what Clunas terms a "knowing subject".

The walls of the models' rooms are decorated with the leftover sketches they have picked up in the studios. The girls have used what they had to hand. They might just as easily have been calendar posters.

\section{Hong Kong 1997}

"Look at the girl," says my father, peering at the poster finally bought and hung in the living room. "Waiting for a friend to go traveling," he reads, taking off his glasses to peer at the fine print across the bottom, "it was printed in Fuzhou Road." "Ah," says my mother, who has grown up in Shanghai, and the dusty photographs of whom are the reasons I am fascinated with these posters in the first place. "Not a very good street."

${ }^{91}$ Zhang Henshui, p.290. 